\title{
Engaging One Health for Non-Communicable Diseases in Africa: Perspective for Mycotoxins
}

\author{
Carina Ladeira ${ }^{1,2,3}$, Chiara Frazzoli ${ }^{4}$ and Orish Ebere Orisakwe ${ }^{5 *}$ \\ ${ }^{1}$ Environment and Health Research Group, Escola Superior de Tecnologia da Saúde de Lisboa - Instituto Politécnico de \\ Lisboa (ESTeSL - IPL), Lisboa, Portugal, '2 Grupo de Investigação em Genética e Metabolismo, Escola Superior de \\ Tecnologia da Saúde de Lisboa - Instituto Politécnico de Lisboa (ESTeSL - IPL), Lisboa, Portugal, ${ }^{3}$ Centro de Investigação e \\ Estudos em Saúde Pública, Escola Nacional de Saúde Pública, ENSP, Universidade Nova de Lisboa, Lisboa, Portugal, \\ ${ }^{4}$ Department for Cardiovascular, Dysmetabolic and Aging-Associated Diseases, Istituto Superiore di Sanità, Rome, Italy, \\ ${ }^{5}$ Toxicology Unit, Faculty of Pharmacy, University of Port Harcourt, Port Harcourt, Nigeria
}

\section{OPEN ACCESS}

Edited by:

Daniela Ceccarelli,

Wageningen Bioveterinary Research (WBVR), Netherlands

Reviewed by: Aida Turrini,

Consiglio per la ricerca in agricoltura e l'analisi dell'economia agraria - Alimenti e

Nutrizione, Italy

Arturo Anadón,

Complutense University of Madrid, Spain Michael Rychlik, Technische Universität München, Germany

*Correspondence: Orish Ebere Orisakwe orishebere@gmail.com

Specialty section: This article was submitted to Environmental Health, a section of the journal

Frontiers in Public Health

Received: 05 July 2017 Accepted: 15 September 2017 Published: 16 October 2017

Citation:

Ladeira C, Frazzoli $C$ and Orisakwe OE (2017) Engaging One Health for Non-Communicable Diseases in Africa: Perspective for Mycotoxins.

Front. Public Health 5:266. doi: 10.3389/fpubh.2017.00266
The role of mycotoxins-e.g., aflatoxins, ochratoxins, trichothecenes, zearalenone, fumonisins, tremorgenic toxins, and ergot alkaloids-has been recognized in the etiology of a number of diseases. In many African countries, the public health impact of chronic (indoor) and/or repeated (dietary) mycotoxin exposure is largely ignored hitherto, with impact on human health, food security, and export of African agricultural food products. Notwithstanding, African scientific research reached milestones that, when linked to findings gained by the international scientific community, make the design and implementation of science-driven governance schemes feasible. Starting from Nigeria as leading African Country, this article (i) overviews available data on mycotoxins exposure in Africa; (ii) discusses new food safety issues, such as the environment-feed-food chain and toxic exposures of food producing animals in risk assessment and management; (iii) identifies milestones for mycotoxins risk management already reached in West Africa; and (iv) points out preliminary operationalization aspects for shielding communities from direct (on health) and indirect (on trade, economies, and livelihoods) effects of mycotoxins. An African science-driven engaging of scientific knowledge by development actors is expected therefore. In particular, One health/One prevention is suggested, as it proved to be a strategic and sustainable development framework.

Keywords: food safety, food security, immune system, risk assessment, risk management

\section{MYCOTOXINS EXPOSURE AND ONE HEALTH (OH)}

The burden of non-communicable diseases (NCDs) increasingly falls on the low- and middleincome countries and highlights the need for prevention of NCDs to be a part of development initiatives to reduce poverty and associated social and health inequalities. NCDs and novel (toxicant-related) zoonoses are linked with new issues in food safety, such as the environmentfeed-food chain and toxic exposures of food producing animals (1). $\mathrm{OH}$ is the joint effort of different discipline and sectors working at national, regional, and global level, to achieve the best possible health for communities, animals and the environment (2). The $\mathrm{OH}$ concept acknowledges the web of links and interrelations that exist between human, animal, and environmental health. Broad institutional changes, implying transdisciplinary, multidimension, multisector, and multiactors 
approaches, and including transboundary harmonization and involvement of health and non-health sectors, are required for $\mathrm{OH}$ to become a widespread approach to health policy (3), both at local and global levels (4).

The role of mycotoxins has been recognized in the etiology of a number of NCDs. Mycotoxins are toxic secondary metabolites of fungal origin (e.g., Aspergillus, Penicillium, and Fusarium genera) and contaminate agricultural products and feeds before or under postharvest. Despite differences in contamination levels, exposure to mycotoxins is apparent globally: calculations show that approximately $24-50 \%$ of all the commodities produced globally, especially basic foodstuffs, can be contaminated by mycotoxins (5-7). In economically developed countries where food safety regulations are in place and climate is temperate [e.g., European Union (EU)], mycotoxins are a problem deserving continuous monitoring, control, and efforts to improve management. In many African countries, the public health impact of mycotoxins exposure is largely ignored even in face of rising incidence of liver cancer (8), esophageal cancer $(9,10)$, neural tube disorders (11), stunted growth (12-14), and other outcomes associated with mycotoxins (15). Moreover, mycotoxins in feeds and derivatives reduce livestock and crop production and influence or even impede export for safety reasons (6). In zootechny, economic losses due to animal consumption of mycotoxin [e.g., aflatoxins (AFs)] contaminated feeds are associated with reduced feed intake, feed refusal, poor feed conversion, diminished body weight gain, increased disease incidence (due to immune suppression), and reduced reproductive capacities (7, 16). Examples of mycotoxins of greatest public health and agro-economic significance include AFs, ochratoxins (OTs), trichothecenes (TCTs), zearalenone (ZEN), fumonisins (Fs), tremorgenic toxins, and ergot alkaloids (17-19). Differences in regulations exist between countries. In the case of AF, for instance, the EU sets limits for AFB1 and for total AFs (B1, B2, G1, and G2) in nuts, dried fruits, cereals, and spices. Limits vary according to the commodity, but range from 2 to $12 \mathrm{ng} / \mathrm{g}$ for B1 and from 4 to $15 \mathrm{ng} / \mathrm{g}$ for total AFs. There is also a limit of $0.050 \mathrm{ng} / \mathrm{g}$ for AFM1 in milk and milk products. Limits of $0.10 \mathrm{ng} / \mathrm{g}$ for B1 and $0.025 \mathrm{ng} / \mathrm{g}$ for AFM1 have been set for infant foods (20). US food safety regulations include a limit of $20 \mathrm{ng} / \mathrm{g}$ for total AFs (B1, B2, G1, and G2) in all foods except milk and a limit of $0.5 \mathrm{ng} / \mathrm{g}$ for AFM1 in milk. Australia and Canada set limits of $15 \mathrm{ng} / \mathrm{g}$ for total AFs (B1, B2, G1, and G2) in nuts, the same as the international limit recommended for raw peanuts by the Codex Alimentarius Commission (CAC).

Mycotoxins are substances with low persistence in the sense that they do not bioaccumulate. Some mycotoxins (e.g. aflatoxin, ochratoxin) are found as parent compound or their metabolites in milk and eggs. However, the main contribution comes from vegetable foods.

AFB1 contamination of feeds is a risk for the health of several farm animals, including fishes; milk is the only food of animal origin where a significant feed-food carryover may occur. A statutory limit $(0.020 \mathrm{mg} / \mathrm{kg}$ feed $)$ is established in Europe $(21,22)$.

Mycotoxins can enter the feed and food chains through direct or indirect contamination pathways. Direct contamination occurs when the food or feed becomes infected by a toxigenic fungus, with the subsequent formation of mycotoxins (23).
Indirect contamination occurs when an ingredient has been previously contaminated by a toxigenic fungus and, even though the fungus has been eliminated during processing, mycotoxins remain in the final product (6).

The changing climate may increase the burden of mycotoxins contamination of feeds and foods globally and affect livestock production in terms of both food safety and security (24). The most common mycotoxins reported in Africa are AFs (43.75\%) followed by Fs (21.87\%), OTs (12.5\%), ZEN (9.38\%), deoxynivalenol (DON) (6.25\%), and beauvericin (BEA) (6.25\%) (25). Rampant and in utero AF exposure in some African countries, including Nigeria, has been found with hematological evidence (biomarkers) in at least $98 \%$ of the population (26). Following the approach of the environment-feed-food chain, $\mathrm{OH}$ strategies should be adopted in Africa for the prevention of mycotoxins exposure.

\section{Mycotoxins in African Staple Foods}

Human ingestion of mycotoxins occurs mainly through contaminated plant food products or carryover in animal food products such as meat and eggs; noticeably, ingestion of mycotoxins' metabolites occurs through dairy products (6). The most risky food commodities are wheat, maize, rice, beans, oleaginous seeds, cocoa, coffee, grapevine, wine, fruits, nuts, spices, and dried food (27-29).

In general, diet in Africa pivots on starchy staple foods/food products based in maize (especially corn fufu), cassava (Manihot esculenta) (e.g., water fufu and garri), plantain, rice, yams/cocoyams, and potatoes (30).

Specifically in Nigeria, carbohydrate intake, such as cassava, yam, and rice constitutes the main diet. Produced by cassava, garri is a roasted granular hygroscopic carbohydrate, popularly consumed by several millions of people regardless of ethnicity and socioeconomic class, making it the most common food product consumed in Nigeria. Garri can be consumed directly in the dry form with peanut, coconut, smoked fish, soaked in water or milk or boiled in water as porridge, popularly called "eba" and eaten with various types of African soups (31). Various groups of molds have been reported to be associated with garri during storage and distribution (32). When present, they can affect the nutritional quality of garri and lead to mycotoxin contamination in case of toxigenic species. OTA has been detected in cocoa and cocoa products in Nigeria (33), and very few reports of its incidence in other crops in Nigeria are available. A high level of $150 \mathrm{ng} / \mathrm{g}$ of the OTA was detected in maize (34) and moldy rice (35) from northern Nigeria. Ayejuyo et al. (36) found very low levels of OTA $(0.0-2.1 \mathrm{ng} / \mathrm{g})$ in 25 brands of imported rice marketed in Lagos metropolis. Data concerning mycotoxins levels in rice from Nigeria are sparse. Makun et al. (35) report the presence of AFB1, ochratoxin A (OTA), and ZEN in moldy rice, and other studies have been based on AFs (37). Ayejuyo et al. (36) assessed and found OTA in imported rice marketed in Lagos metropolis. Makun et al. (38) provided for the first time the mycotoxin profile of home-grown Nigerian rice with respect to seven of the most important mycotoxins worldwide, namely, AFs, OTA, ZEN, DON, T-2 toxin, fumonisin B (FB), and patulin (PAT). The study reports AFs detected in all samples, total AF concentrations ranging from 28 to $372 \mathrm{ng} / \mathrm{g}$. ZEN (53.4\%), DON (23.8), FB1 (14.3\%), and FB2 (4.8\%) were also found in rice, 
although at relatively low levels (38). The acceptable limits for ZEN, FBs, and DON are 30-200, <1,000, and 750-2,000 ng/g, respectively $(39,40)$. AF levels exceeding limits $(10 \mathrm{ng} / \mathrm{g})$ set by the 77 countries, including the EU, that regulate AFs were found in the homegrown Nigerian rice (38-40). OTA was found in $66.7 \%$ of the samples, with concentrations $(134-341 \mathrm{ng} / \mathrm{g})$ above the maximum levels $(2-50 \mathrm{ng} / \mathrm{g})$ in cereals for human consumption. Mycotoxins levels in some agricultural crops and foods in some African countries are shown in Table 1. The limit of quantification varies between 0.3 and $10 \mu \mathrm{g} / \mathrm{kg}$ depending on the mycotoxin.

\section{Mycotoxins in African Street Food}

Common local street-vended snacks in Nigeria include beans cake (akara), roasted, dried and milled maize and groundnuts (donkwa), groundnut cake (kulikuli), fibrous powdery form of cassava (lafun), cheese curds (wara), and yam flour. Reports on mycotoxin contamination of these snacks have mainly focused on Aspergillus and Penicillium mycotoxins, such as AFs and OTA with scanty record on other fungal metabolites including Fusarium mycotoxins $(66,67)$. Snack samples made separately from corn, groundnut, and wheat were contaminated by total AFs concentrations at levels exceeding the limits for total AFs in foods (15 ng/g) as recommended by the National Agency for Food and Drug Administration and Control (NAFDAC), that is the regulatory body in Nigeria $(66,67)$. Noticeably, peanut cake, popularly called "Kulikuli," is highly consumed due to its high protein and lipid content as well as its affordability by the many low- and middle-income people in sub-Sahara Africa (63). The AFB1 levels in kulikuli from different parts of Nigeria were about 200 -folds more than the $10 \mu \mathrm{g} / \mathrm{g}$ NAFDAC limit and also higher than levels reported previously in peanut and peanut products $(64,82,83)$. Rubert et al. (84) reported high levels of AFs (26 ng/g) in Nigerian baked coconut; $\alpha$-zearalenol $(\alpha$-ZOL) $(54 \mathrm{ng} / \mathrm{g})$ was found in coconut candy. Taken together street-vended snacks (cassava-, coconut- and groundnut-based types) in Nigeria seem contaminated by AFs. In Benin, Nigeria's closest neighbor, AFB1 was detected in $93.3 \%$ of peanut cake samples at concentrations above the EU limit (85). The consumption of peanut cakes with high levels of AFB1 portends a public health concern since the consuming population is school-aged children and young adults in their active economical and reproductive age.

Aspergillus flavus and Alternaria tenuissima have been isolated from local Nigerian foods $(86,87)$. The $75-94.1 \%$ prevalence of nephrotoxic OTA at level (5 ng/g) regarded as unsafe by the EU in maize, that is a major component of weaning foods and animal feeds in Nigeria, makes its contamination by OTA a serious issue (70, 88, 89). Aflatoxigenic strains of A. flavus and Aspergillus parasiticus have been reported in peanut and peanut products in Africa $(82,90)$. A. flavus SBG is morphologically similar to A. flavus S-type strains and not only produces small sclerotia but also can synthesize large amounts of both AFs B and G. The SBG strain type has a more limited distribution and may be an important source of AF contamination in West Africa $(91,92)$. Perrone et al. (93) investigated the incidence of Aspergillus sect. Flavi and the level of AF contamination in 91 maize samples from farms and markets in Nigeria and Ghana. There was higher contamination of the farm samples than the market samples, suggesting that AF exposure of rural farmers is higher than previously estimated. High levels of AFs B and G and lower income of A. flavus SBG strains suggest that long-term chronic exposure to this mycotoxin are much higher health risk in west Africa than is the acute toxicity due to very highly contaminated maize in east Africa (93).

\section{Dietary Exposure to Mycotoxins' Mixtures}

Daily exposure to mycotoxins' mixtures through consumption of single food sample is proven. Data on the co-occurrence of the principal mycotoxins in foods and beverages are increasing worldwide due to the availability and use of modern and sensitive LC-MS/MS methodologies suitable for simultaneous determination of mycotoxins and other fungal metabolites (94). The presence of mixtures of AFB1, OTA, and ZEN was reported in samples of breakfast cereals commercialized in Spain (94, 95). The study conducted by Solfrizzo et al. (94) on mycotoxins exposure in southern Italy confirmed the presence of DON and OTA in almost all urinary samples. In this study, $6 \%$ of urine samples contained AFM1, i.e., a metabolite of mycotoxin mainly found in maize (AF M1 is not present in Maize) and derivatives although these products are not staple foods in Italy where they are consumed as chips, polenta, popcorn, beer, cornflakes, snacks, muesli, and mixed cereals. From a risk assessment stand point, the co-occurrence of mycotoxins is very important though vaguely understood: indeed, recent in vitro data highlight potential additive or synergistic interactions (96-99). Notwithstanding this, also in Europe there are few published studies on the cooccurrence of mycotoxins [e.g., Ref. $(100,101)]$. Co-contamination with AFs, OTA, and ZEN is very common in Nigeria, and up to five mycotoxins were detected in a single rice sample; AFs (B1, B2, G1, and G2) were found in all samples (38). The presence of AFs and OTA in this Nigerian staple food at levels exceeding the limits set by international regulatory bodies along with the co-occurrence of other toxicants with possible toxic synergistic effect made the studied rice sample unsuitable for human and animal consumption and raise national public health concerns (38). Kimanya et al. (102) confirmed co-occurrence of AFs with DON and Fs from maize based meals in northern Tanzania. In a survey of mycotoxins in traditional maize based opaque beers in Malawi, it was estimated that consumption of 1.0-6.0 L of this local beverage results in a daily FB1 and FB2 exposure of $29-174 \mu \mathrm{g} / \mathrm{kg}$ body weight (bw)/day [i.e., >provisional maximum daily intake of $2 \mu \mathrm{g} / \mathrm{g}$ bw/day set by the Joint FAO/ WHO Expert Committee on Food Additives (JECFA)] and AF exposure of $1.5-9.0 \mu \mathrm{g} / \mathrm{kg}$ bw/day for a $60 \mathrm{~kg}$ adult (103). This is of significant public health importance since this singular source alone can add to the body burden due to AFs and Fs dietary exposure among beer consumers (103). OTA, ZEN, DON, NIV, and other less reported mycotoxins such as citrinin, alternariol, cyclopiazonic acid, sterigmatocystin, moniliformin, BEA, and enniatins were detected in various food samples from Burkina Faso and Mozambique (41). The quantification of at least 28 toxic fungal metabolites in a single sample strongly suggests the huge variety of mycotoxin co-exposure in Africa (41).

Ngoko et al. (104) report 50-26,000 ng/g Fs, 100-1,300 ng/g DON, and 50-180 ng/g ZEN in maize samples from Cameroon. 
TABLE 1 | Mycotoxins levels $(\mu \mathrm{g} / \mathrm{kg})$ in the crops and foods in some African countries.

\begin{tabular}{|c|c|c|c|c|}
\hline Country & Mycotoxin & Food stuffs & Concentration $(\mu \mathrm{g} / \mathrm{kg})$ & Reference \\
\hline Mozambique & $\begin{array}{l}\text { Fumonisin } \mathrm{B}_{1} \\
\text { Fumonisin } \mathrm{B}_{2} \\
\text { Fumonisin } \mathrm{B}_{3} \\
\text { DON } \\
\text { DON-glucoside } \\
\text { NIV } \\
\text { ZEA } \\
\text { Citrinin }\end{array}$ & $\begin{array}{l}\text { Maize } \\
\text { Maize } \\
\text { Maize } \\
\text { Maize } \\
\text { Maize } \\
\text { Maize } \\
\text { Maize } \\
\text { Maize }\end{array}$ & $\begin{array}{c}159-7,615 \\
27.7-3,061 \\
26.6-777 \\
116-124 \\
12.6-32.5 \\
20.2-45.9 \\
10.9-18.1 \\
276-5,074\end{array}$ & Warth et al. (41) \\
\hline Malawi & $\mathrm{AF}$ & $\begin{array}{l}\text { Sorghum } \\
\text { Sorghum for thobwa drink } \\
\text { Sorghum for beer }\end{array}$ & $\begin{array}{c}1.7-3.0 \\
6.1-54.6 \\
4.3-1,138.8\end{array}$ & Matumba et al. (42) \\
\hline $\begin{array}{l}\text { Botswana } \\
\text { Sudan }\end{array}$ & $\begin{array}{l}\text { AFs } \\
\text { AFs } \\
\text { AFB }_{1}\end{array}$ & $\begin{array}{l}\text { Peanut } \\
\text { Sesame oil } \\
\text { Groundnut oil } \\
\text { Peanuts butter } \\
\text { Sesame unpeeled }\end{array}$ & $\begin{array}{c}12-239 \\
0.2-0.8 \\
0.6 \\
21-170 \\
0.4-14.5\end{array}$ & $\begin{array}{l}\text { Mphande et al. (43) } \\
\text { Idris et al. (44) } \\
\text { Elshafie et al. (45) } \\
\text { Kollia et al. (46) }\end{array}$ \\
\hline Tanzania & $\begin{array}{l}\text { FUMs } \\
\text { AFs }\end{array}$ & $\begin{array}{l}\text { Maize } \\
\text { Maize }\end{array}$ & $\begin{array}{c}11,048 \\
158\end{array}$ & Kimanya et al. (47) \\
\hline $\begin{array}{l}\text { Tanzania and DR Congo } \\
\text { Zambia }\end{array}$ & $\begin{array}{l}\text { AFs } \\
\text { FUMs } \\
\text { AF }\end{array}$ & $\begin{array}{l}\text { Maize } \\
\text { Maize } \\
\text { Maize }\end{array}$ & $\begin{array}{c}0.04-120 \\
20,000 \\
0.7-108.74\end{array}$ & $\begin{array}{l}\text { Manjula et al. (48) } \\
\text { Mukanga et al. (49) } \\
\text { Kankolongo et al. (50) }\end{array}$ \\
\hline $\begin{array}{l}\text { Uganda } \\
\text { Kenya }\end{array}$ & $\begin{array}{l}\text { AFs } \\
\text { AFs }\end{array}$ & $\begin{array}{l}\text { Groundnuts, cassava, millet, sorghum flour } \\
\text { Animal feed and milk } \\
\text { Maize } \\
\text { Maize } \\
\text { Peanut }\end{array}$ & $\begin{array}{c}0-55 \\
>5 \\
>20 \\
1-46,400 \\
0-7,525\end{array}$ & $\begin{array}{l}\text { Kitya et al. (51) } \\
\text { Kang'ethe and Lang'a (52) } \\
\text { Daniel et al. (53) } \\
\text { Lewis et al. (54); Mwihia et al. (55) } \\
\text { Mutegi et al. (56) }\end{array}$ \\
\hline Ethiopia & $\begin{array}{l}\text { AFs } \\
\text { AFs } \\
\text { OTA } \\
\text { DON } \\
\text { FUM } \\
\text { ZEA }\end{array}$ & $\begin{array}{l}\text { Shiro and ground red pepper } \\
\text { Sorghum, barley, teff, and wheat } \\
\text { Sorghum, barley, and wheat } \\
\text { Sorghum } \\
\text { Sorghum } \\
\text { Sorghum }\end{array}$ & $\begin{array}{c}100-525 \\
0-26 \\
54.1-2,106 \\
40-2,340 \\
2,117 \\
32\end{array}$ & $\begin{array}{l}\text { Fufa and Urga (57) } \\
\text { Ayalew et al. (58) }\end{array}$ \\
\hline Nigeria & $\begin{array}{l}\text { OTA } \\
\text { AFs } \\
\text { OTA }\end{array}$ & $\begin{array}{l}\text { Rice } \\
\text { Edible tubers "tiger nuts" } \\
\text { Edible tubers "tiger nuts" } \\
\text { Sorghum } \\
\text { Dried yam } \\
\text { Dry roasted groundnut } \\
\text { Groundnut cake } \\
\text { Peanut cake (kulikuli) } \\
\text { Corn-based snacks } \\
\text { Nut-based snacks } \\
\text { Wheat-based snacks } \\
\text { Fin fish } \\
\text { Shell fish } \\
\text { Rice } \\
\text { Weaning food } \\
\text { Maize } \\
\text { Millet } \\
\text { Sorghum } \\
\text { Sesame } \\
\text { Fonio (acha) } \\
\text { Cassava (garri) }\end{array}$ & $\begin{array}{c}28-372 \\
454 \\
10-120 \\
10-80 \\
27.1 \\
52.4 \\
20-455 \\
13-2,824 \\
12.0-30.0 \\
0.0-6.0 \\
0.0-50.0 \\
1.05-10.00 \\
4.23-5.90 \\
134-341 \\
4.6-530 \\
0-139.2 \\
10.20-46.57 \\
0-29.50 \\
1.90-15.66 \\
1.38-23.90 \\
3.28-22.73\end{array}$ & $\begin{array}{l}\text { Makun et al. (38) } \\
\text { Adebajo (59) } \\
\text { Bankole and Eseigbe (60) } \\
\text { Salifu (61) } \\
\text { Bankole and Mabekoje (62) } \\
\text { Bankole et al. (63) } \\
\text { Akano and Atanda (64) } \\
\text { Ezekiel et al. (65) } \\
\text { Ezekiel et al. (66, 67) } \\
\text { Olajuyigbe et al. (68) } \\
\text { Oluwafemi and lbeh (69) } \\
\text { Makun et al. (70) }\end{array}$ \\
\hline Ghana & $\begin{array}{l}\text { AFs } \\
\text { Fs }\end{array}$ & $\begin{array}{l}\text { Maize } \\
\text { Maize }\end{array}$ & $\begin{array}{c}0.7-355 \\
70-4,222\end{array}$ & $\begin{array}{l}\text { Kpodo (71) } \\
\text { Kpodo et al. (72) }\end{array}$ \\
\hline Benin & AFs & $\begin{array}{l}\text { Maize } \\
\text { Chips } \\
\text { Dried yams } \\
\text { Cowpea }\end{array}$ & $\begin{array}{c}5 \\
2.2-220 \\
2.2-220 \\
\text { nd }\end{array}$ & $\begin{array}{l}\text { Hell et al. (73) } \\
\text { Bassa et al. (74) } \\
\text { Mestres et al. (75) } \\
\text { Houssou et al. (76) }\end{array}$ \\
\hline
\end{tabular}


TABLE 1 | Continued

\begin{tabular}{|c|c|c|c|c|}
\hline Country & Mycotoxin & Food stuffs & Concentration $(\mu \mathrm{g} / \mathrm{kg})$ & Reference \\
\hline Benin, Mali, and Togo & & Baobab leaves, hot chili, and okra & $3.2-6.0$ & Hell et al. (77) \\
\hline \multirow{3}{*}{ Burkina Faso } & DON & Maize & 31.4 & Warth et al. (41) \\
\hline & ZEN & Maize & $11.0-15.8$ & \\
\hline & Citrinin & Maize & $531-5,074$ & \\
\hline \multirow[t]{4}{*}{ South Africa } & FUMs & Maize & $222-1,142$ & Burger et al. (79) \\
\hline & Fs & Compound feeds & $104-2,999$ & Njobeh et al. (80) \\
\hline & DON & Compound feeds & $124-2,352$ & \\
\hline & ZEN & Compound feeds & $30-610$ & \\
\hline Lesotho & ZEN & Sorghum beer & 50 & Gillbert (81) \\
\hline
\end{tabular}

nd, not detectable; ZEN, zearalenone; DON, deoxynivalenol; AFs, aflatoxins; OTA, ochratoxin A; NIV, nivalenol.

Limit of quantification: $D O N=10, N I V=10, Z E N=5, O T A=0.3 \mu \mathrm{g} / \mathrm{kg}$.

Detectable levels of AF ranged between 5.2 and $14.5 \mathrm{ng} / \mathrm{g}$ in other widely consumed foods in Cameroon, namely, cassava balls and cassava pellets (105). A simultaneous occurrence of mycotoxins ( $\mathrm{FB}_{1} 41 \%$, AF 51\%, ZEN 57\%, DON 65\%, and OTA 3\%) in human food commodities from Cameroon has also been reported (80). In another study from Cameroon, total AF levels exceeded the maximum limits of the European Commission (EC) regulations (30). Taken together, the widespread nature and high levels of multiple mycotoxins occurring in staple foods suggest high exposure levels that could have severe health implications in sub-Sahara Africa.

AFM1 in human breast milk is an important health risk for infants (16). The chronic intake of AF contaminated food could increase stillbirths and neonatal mortality, immune suppression with increased susceptibly to infectious diseases such as pneumonia, stunting of growth (33), and HIV/AIDS (106). In many countries, because animals are usually milked individually at the household doorstep mycotoxins consumption can be very high (107-109). Although the minute of mycotoxins through food of animal origin may be seemingly innocuous in the general population, vulnerable groups may not be spared, especially the genotoxic carcinogens such as AFs.

\section{Additional Exposure Route: Mycotoxins in African Indoor}

Inhalation of contaminated airborne aerosols can represent an additional route of mycotoxin exposure. Nowadays, people spend about $90 \%$ of their time in indoors environment due to working or resting (31). However, in many parts of the world, homes, schools, and workplaces are contaminated with airborne molds and other biological contaminants $(110,111)$.

Mycotoxins can be found in airborne particulates of environments where susceptible commodities are treated, such as warehouses, harbors, laboratories, and specific occupational settings where products/materials that are commonly contaminated (e.g., waste, feed, and animal production) are handled (112-115).

Poultries fungal burden is mainly affected by the kind of litter applied in pavilions (112), whereas in swine it is mainly affected by the feeding operations due to feed fungal contamination
$(113,114)$. Waste management industries pose another challenge regarding workplaces fungal contamination, in waste water treatment plants and in solid waste management industries the main source are the waste water and the waste that need to be treated (115).

Moreover, the presence of mycotoxins in domestic households as a consequence of inappropriate hygiene conditions has been demonstrated, with immunosuppressive effects due to the inhibition of phagocytosis and of alveolar macrophage functions (27). Children, elderly, patients on immune suppressants, and with respiratory diseases are more susceptible to contamination by indoor fungi (110). A. flavus has been isolated from indoor environment like hospitals in Nigeria $(116,117)$. Although the presence of indoor fungi by mold contamination is related with dampness of the indoor environment and swampy locations, researches have indicated fungal presence as well in houses without these characteristics (111). The highest isolation rates (Rhizopus sp., for instance) were achieved from high residential density areas, probably an effect of overcrowding, poor sanitation and high arthropod infestation. Factors such as absence of basic facilities for drainage and waste disposal and dumps in proximity of residential homes do favor indoor mold contamination $(118,119)$.

\section{RISK ASSESSMENT}

Mycotoxins are metabolized in liver and kidneys and also by microorganisms in the digestive tract (7). Chemical structure and toxicity of mycotoxin metabolites excreted by animals or found in their tissues are different from the parent molecule. Toxicity depends of factors such as type of toxin, dose ingested, duration of exposure, age, and sex (29). The WHO (120) estimated that AFs were responsible for nearly 20,000 deaths each year, 3,000 of them on the African continent. The International Agency for Research on Cancer (IARC) classified AFB1 in group 1 "carcinogenic to humans." AFB1 is the most potent natural carcinogen and is usually the major AF produced by aflatoxigenic strains. The no observed-adverse effect level is not applied for genotoxic carcinogens, therefore no threshold is assigned to AFB1. 
In particular, AFs are potent hepatotoxins. Chronic exposure to small doses of AF for prolonged periods (e.g., through the diet) has been associated with human hepatocellular carcinomas, which may be compounded by other carcinogens, such as hepatitis $B$ virus. Hepatocellular carcinoma (HC) is the third most common cause of death from cancer in Africa (121). Approximately 250,000 deaths are caused by HC in sub-Saharan Africa annually and can be attributed to risk factors such as high daily intake $(1.4 \mu \mathrm{g})$ of $\mathrm{AF}$ and high incidence of hepatitis $\mathrm{B}(17,19)$. As well as causing liver cancer, AFs have been associated with other health problems in people such as stunting in children and immune suppression (16). Chronic exposure to AFs is associated with impaired immunity and malnutrition, therefore also with malaria and HIV/AIDS $(21,22,122,123)$. A study in Ghanaian adults reported that AFs could cause impairment of human cellular immunity that could decrease resistance to infections (19). Kwashiorkor, a disease usually considered a form of protein energy malnutrition, has long been linked to AF exposure, along with chronic gastritis and childhood cirrhosis $(14,124)$. Acute exposure to large doses $(>6,000 \mu \mathrm{g})$ may precipitate severe acute liver injury with high morbidity and mortality (125). Symptoms of acute toxicity include reduced liver function, derangement of blood clotting mechanism, icterus (jaundice), and a decrease in essential serum proteins synthesized by the liver. Acute AF exposures have been associated with epidemics of acute toxic hepatitis in Africa with death rates ranging from 10 to $60 \%$ $(6,17)$. Other general signs of aflatoxicosis are edema of the lower extremities, abdominal pain, and vomiting. An outbreak of acute aflatoxicosis in Kenya in 2004 caused 125 deaths among 317 people that consumed AF contaminated maize (92).

Aflatoxin M1, OTA, and FB1, FB2 are classified in group 2B "possibly carcinogenic to humans." Chronic ingestion of Fs has been linked as possible risk factor for the occurrence of esophageal cancer in areas, such as the former Transkei region of South Africa, where Fs exposure from contaminated maize is high (126). There is a specific $p 53$ codon 249 mutation in the plasma of liver tumor patients from West Africa (Gambia) after exposure to AFs $(127,128)$. In a study of HIV and hepatocellular and esophageal carcinomas, related to consumption of mycotoxinprone foods in sub-Sahara Africa, the relation between cancer and food suggested that Fs contamination rather than AF is the most likely factor in maize promoting HIV (129). OTA could also be associated with immunotoxic and neurotoxic effects (29).

Other mycotoxins, i.e., PAT, ZEN metabolites, some TCTs, in particular T-2 toxin, nivalenol (NIV), and DON, are considered by IARC as "not classifiable as to its carcinogenicity to humans" (group 3).

With special emphasis on infertility, that is an ongoing global reproductive health problem, also in Africa, in vivo and in vitro studies have shown that ZEN and metabolites $[\alpha-Z O L$ and $\beta$-zearalenol ( $\beta$-ZOL)], DON, OTA, and AFB1 adversely affect fertility by arresting steroidogenesis. Exposure to these mycotoxins precipitate deleterious effects on the spermatozoa, Sertoli and Leydig cell function, oocyte maturation, and uterine and ovarian development and function in in vivo, ex vivo, and in vitro experimental models (130-134). Mycotoxins can induce oxidative stress and result in damage of sperm DNA (135), reduced fertilization rates and embryo quality (136). Mycotoxins have also been implicated as endocrine disruptors altering the steroid hormone homeostasis and interfering with receptor signaling (137-140). Concentrations of AFB1 significantly higher in the semen of infertile men than in controls (semen of fertile) have been reported by Ibeh et al. (141), thus suggesting that exposure to AFB1 could be a causative factor in male infertility in Nigeria. At least $50 \%$ of infertile men with high seminal concentrations of AFB1 had a greater percentage of abnormalities in sperm count, motility and morphology compared with the fertile men (10-15\%) (141). These observations were comparable to male rats fed with AFB1 contaminated feeds $(8.5 \mu \mathrm{g} / \mathrm{g}$ of feed) for 14 days (141). Similarly, semen and blood levels of AFB1 which ranged from 700 to $1,392 \mathrm{ng} / \mathrm{mL}$ and exceeded the WHO recommended level have reported in infertile men attending the infertility clinic in Nigeria (142). The high prevalence of male infertility in Africa (20-35\%) (143-146) as well as the declining sperm count (147) motivate reproductive health experts in investigating the role of mycotoxins (148). Since endocrine disrupting chemicals are known to cause endometriosis, premature ovarian failure, and polycystic ovary syndrome, mycotoxins may also be involved in female reproductive disorders (149).

\section{Markers and Biomarkers}

Mycotoxins are measured in feeds, food, air, or other environmental samples for environmental monitoring purposes, whereas the presence of adducts and metabolites are assayed in human or animal tissues, fluids, and excreta for biological monitoring (150). A challenge in the field of internal exposure assessment is to develop accurate and reliable biomarkers. The biomarker approach is a promising tool for measuring toxin-mediated biological perturbations or the amounts of mycotoxins present in the matrix (28). In molecular epidemiology, it is possible to demonstrate the association between putative carcinogens and specific cancers (150). Biological markers of AFs, OTA, and Fs exposure have attracted the attention for mycotoxin biomonitoring studies. However, while AFs and OTA biomarkers have been successfully applied and validated over the last decade, large drawbacks remain to find a suitable Fs biomarker (28).

Biomonitoring of AFs can be done by quantifying AF metabolites in blood, milk, and urine. Indeed, the first studies in which biomarkers where used to determine human exposure to food pollutants involved AFB1. In these studies, correlation between AFB1 intake and urinary AFM1 excretion was statistically achieved and the exposure biomarker validated. The mean urinary AFM1 level in Cameroon (30) was similar to that observed in adults in Ghana (range: nd-0.115 $\mu \mathrm{g} / \mathrm{L}$ ) (151) and fully weaned that of Guinean children (152). A similar range was observed among pregnant women in Egypt (0.004-0.409 $\mu \mathrm{g} / \mathrm{g}$ creatinine) (153). Ghana and Guinea are recognized as high-risk regions for AF exposure, whereas Egypt is regarded as moderate when compared with sub-Saharan Africa (152, 154-156). The estimates of tolerable daily intake of several mycotoxins are exceeded in Africa (30). In a pilot, cross-sectional and correlational study conducted in eight rural communities in northern Nigeria to investigate mycotoxin exposures in volunteers, urinary 
biomarker levels were correlated with mycotoxin levels in foods consumed the day before urine collection in all age categories, suggestive of chronic (lifetime) exposures (10). In the urines with detectable AFM1, it was estimated that the mean intake of AFB1 was $0.67 \mathrm{ng} / \mathrm{kg}$ bw/day ( $\max =2.5 \mathrm{ng} / \mathrm{kg}$ bw/day). Higher AFM1 urinary levels have been detected in children from Sierra Leone children (157).

Albumin-bounded AFB1 and AFB1-DNA adducts in urine have also been explored for exposure assessment studies (28). Numerous studies have shown that carcinogenic potency is highly correlated with the extent of total DNA adducts formed in vivo (150). Excreted DNA adducts and blood protein adducts can also be monitored: the AFB1- $\mathrm{N}^{7}$-guanine adduct represents the most reliable urinary biomarker for AF exposure but reflects only recent exposure (158). High AF-albumin adduct levels in maternal blood, cord blood, infant blood, and children's blood have been associated with poorer growth indicators and impaired markers of human immunity as shown by lower levels of secretory immunoglobulin A in saliva of Gambian children $(159,160)$. High levels of AFB1-albumin adducts were associated with low percentages of certain leukocyte immune phenotypes in Ghana (161). The chronic/dietary exposure to AF is evident from the presence of AFM1 in human breast milk (162) and umbilical cord blood samples (163), with serious implications for the next generation (109). Home-grown maize contamination led to arguably the largest fatal aflatoxicosis outbreaks in rural communities of Kenya, in which AF-albumin adducts were independently confirmed in the exposed (164). In another study from Kenya, wasting in children was related to consumption AF contaminated flour (165). In Ghana, low birth weight was shown to have an association with mothers' AF-albumin adduct levels (166). There is a dose-dependent decrease in height and weight for age in AF exposed children in a study carried out in Togo and Benin in West Africa $(123,167)$.

Mycotoxin-producing molds have lately been found to infect the intestinal tract to cause leaky gut, thus exerting important immunosuppressive activity, and produce neurotoxins (168). OTA, that has nephrotoxic, hepatotoxic, immunotoxic, and genotoxic effect and induces carcinogenicity, teratogenicity, and mutagenicity, has also been seen to cause dysregulation of several gene expression including the upregulation of SOX9 (169), i.e., a gene involved in the development of the male phenotype and has been detected in autistic cases (170). It has recently been posited that single nucleotide polymorphisms in NLGN4X 3'UTR and illegitimate microRNA-inducing OTA could be a possible biological mechanism reflecting the gene-environment interaction in patients without causative mutations $(171,172)$ and suffering from dysbiosis and leaky gut (173). Although there seem to be no published data on population-based estimates of prevalence of pervasive developmental disorders from African region, the prevalence of autism spectrum disorder (ASD) among children with developmental disorders in Egypt and Tunisia has been documented as 33.6 and $11.5 \%$, respectively $(174,175)$. The ASD is an increasing neurodevelopmental disorder with a broad phenotype, appearing by 3 years of age: it often shows comorbid situations, such as mental retardation, epilepsy, and recurrent gastrointestinal abnormalities. In Nigeria about $0.9 \%$ of the children under the age of 3 years manifested neurodevelopmental delays in a recent survey (176). It is even feared that this value may be higher considering late diagnosis (176). Like most aspects of ASD, the mycotoxin impact on this prevalence remains unknown.

Human health risk assessments of Fs hinge on maize consumption. Maize consumption can be $<10 \mathrm{~g} /$ person/day in various European countries, but up to $400-500 \mathrm{~g} /$ day in rural Africa (177), with a 90 percentile value of over $700 \mathrm{~g} /$ person/day (178). The implication of this socio-geographical dietary variation with respect to attaining the provisional maximum tolerable daily intake (PMTDI) of $2 \mathrm{ng} / \mathrm{g}$ bw/day of Fs is enormous. Whereas a European consumer at an assumed bw of $60 \mathrm{~kg}$ would need to consume $10 \mathrm{~g}$ maize at an Fs contamination level of $12,000 \mathrm{ng} / \mathrm{g}$, an African who consumes $500 \mathrm{~g} /$ day would exceed the PMTDI if the contamination level was above $240 \mathrm{ng} / \mathrm{g}$ (179). The detrimental effects of Fs on the developing fetus and young infants are now known from both experimental and epidemiological researches. Transkei region in South Africa and Tanzania where Fs exposure is high is known to have elevated incidences of neural tube defects and growth retardation (180, 181). Fs interfere, via depletion of sphingolipids, with the folate receptor, thus inhibiting the uptake of folate and eventually leading to cellular folate deficiency and neural tube defects (182), that can be prevented in experimental animals by folate supplementation (183).

\section{PERSPECTIVES FOR RISK MANAGEMENT IN WEST AFRICA}

Many African countries have some mycotoxin regulations but only for AFs (or a few other mycotoxins) in specific foods, or no regulations at all. Even when standards are in place, severe mycotoxin-poisoning outbreak occurs in Africa (92). Indeed, good practices and recommendations for the field management of risk of mycotoxins occurrence would be strategic for investment of public, non-governmental organization, and private funds at the scale of the subsistence farmer, the smallholder, and through to a more advanced value chain (184).

The multiplicity of origins of fungal infections implies that strategies for prevention of mycotoxins contamination must be applied at an integrative level along all the food production chain. There are three steps of intervention that must be of concern: prevention (i) before any fungal infestation, (ii) during the period of fungal invasion of plant material and mycotoxins production, and (iii) when agricultural products have been identified as heavily contaminated $(7,185)$.

Risk mitigation practices cover pre- and postharvest:

(i) Predictive models. Weather conditions (e.g., hot and humid tropical climate that favors fungal proliferation) are the most influential parameter on mycotoxins contamination and fungal infection and growth $(186,187)$. Predictive models for mycotoxins occurrence based on regional weather data would be a valuable tool to estimate the risk of contamination (188). In a study that examined AF exposure 
in pregnant Gambian women having staple food in refined white rice, millet, or maize with groundnut sauce, AF exposure throughout pregnancy was found, with higher levels in the dry season. Women in later stages of pregnancy showed higher levels of AF-albumin adducts than those in earlier stages of pregnancy in the dry season (189).

(ii) Preharvest interventions. Good agricultural practices such as sanitation, early sowing date, balanced nitrogen fertilization, moderate plant density, breeding for resistance to drought, insect pest damage or fungal infections, biological control, early harvesting, and moisture levels and proper handling during harvesting. An integrated program involving plant maturation, nutrition, and insect control is crucial $(9,185)$, along with proper and timely crop rotation, tillage, and fungicide administration $(7,150)$. Biogeographical agricultural models of cultivated plants could also be useful.

(iii) Postharvest strategies (transportation, marketing, and processing). Control of factors such as temperature, humidity, $\mathrm{pH}$, packaging, cross contamination by practices like sorting and complete drying decrease contamination during storage (46). In case of toxin manifestation, measures are required that act specifically against certain types and groups of toxins $(7,150)$.

(iv) Detoxification strategies for contaminated feeds are studied to reduce or eliminate the adverse effect of mycotoxin. The addition to the animal's diet or the treatment of contaminated feeds with mycotoxin-binding agents may be useful to protect animal health and avoid milk contamination by the carcinogenic AFM1 metabolite. However, mycotoxin binders may impact animal health, e.g., by interfering with the absorption of nutrients or medications $(7,190)$. Traditional techniques that could reduce/detoxify mycotoxins during food processing are studied (191).

(v) In house protective practices, such as proper food storage, dietary diversity-where possible-, and vaccination against $\mathrm{HBV}$ to prevent the synergism of AF exposure and chronic HBV infection in liver cancer risk (7, 95, 150, 192-194). Significant building blocks for mycotoxins risk management do exist in West Africa, such as the following:

- Surveillance and monitoring of environmental/food matrices experiences. Biomonitoring of mycotoxins in biological fluids such as blood or urine is useful to generate reliable information on internal exposure at individual level compared with dietary assessments (10). Validated biomarkers of exposure are available, such as urinary metabolites, DNA, and protein (albumin) adducts (15, 192). The OTA levels found in Nigerian-grown rice and maize are within the lower limits of concentrations (200$1,000 \mathrm{ng} / \mathrm{g}$ ) that have been linked to porcine nephropathy in Bulgaria (195). There has been a speculation about the contribution of OTA to raise the incidence of chronic renal diseases in Nigeria in conjunction with malaria, hypertension, and diabetes conditions. Poor record of renal registry in Nigeria has hampered the tracking of chronic renal disease; however, available hospital data revealed that chronic renal failure accounts for about $10 \%$ of medical admissions in Nigeria, and extrapolating this, puts the frequency figure between 200 and 300 patients per million of population (196).

- Application of biomarkers. In a pilot study using multi-urinary biomarkers among rural residents in northern Nigeria, Ezekiel et al. (10) detected mycotoxin in all age categories. Their observations suggest chronic/lifetime exposures, and some exposures were higher than the tolerable daily intake. The study developed in Cameroon by Abia et al. (30) used for the first time in Africa a novel multi-mycotoxin assay utilizing LC-MS/MS to determine the frequency of occurrences and levels of several mycotoxins, or their metabolites in urine.

- Experiences of total diet studies (TDSs). Dietary intake estimate should include data on consumption of raw and processed foods (100) to assess average dietary exposure and identify excessive consumer subgroups. TDSs are often used as a risk assessment tool to evaluate exposure and-when performed periodically- exposure trends in the general population and (more vulnerable consumers such as children or diseased subjects, or higher consumers) high-risk subgroups. TDSs differ from traditional food monitoring in two major aspects: (i) chemicals are analyzed in food in the form in which it is consumed and (ii) cost-effectiveness, because composite samples (more ingredients grouped) after kitchen processing are analyzed. As made by European participants in the SCOOP [Scientific Cooperation on Questions relating to Foods (197)] exercises, African countries could group by region and collect, and harmonize knowledge on the status of mycotoxins contamination of raw material and food products (197). Preliminary experiences of TDSs do exist in West Africa, along with its methodology and methods (198).

- Seminal governance framework based on $\mathrm{OH}$. OH integrates efforts for building a governance national strategy based on the linked and mutually supported protection of environment, farm animals and human well-being (199).

- Seminal toxico-vigilance (TV) system. The TV system aims at updating (and harmonizing) registers on information on incidence of poisoning in communities (200).

- Risk assessment and advices for food regulations. Mycotoxins regulations have been established in about 100 countries, out of which 15 are African, to protect the consumer. As in the case of Europe (the European Food Safety Authority), an African independent body could be established with the task of independent science-based risk assessment on food and feed. So far, the JECFA, that is an international committee administered jointly by FAO and WHO, serves as an independent scientific committee which performs risk assessment and provides advice to FAO, WHO, and the member countries of both organizations. The requests for scientific advice are for the main part channeled through the CAC in its work to develop international food standards and guidelines under the Joint FAO/WHO Food Standards Programme. 


\section{African Turning Point on Mycotoxins}

Mycotoxins are now recognized as major cause of food intoxications in SSA. Many economically developing countries have realized that reducing mycotoxins level in foods will not only reduce financial burden on health care but also confer international trade advantages such as exports to more attractive and remunerative markets. Moreover, reducing mycotoxins level means facing lowered animal production, lowered yields in agriculture, and lower market value $(5,7,17)$.

The study from Somorin et al. (101) concerning the cooccurrence of AFs, OTA, and citrinin in egusi melon seed from Nigeria is one of the examples to explain the basis for increasing border rejection of melon seed consignments from Nigeria to EU as highlighted in the European Rapid Alert System for Food and Feed (RASFF) (201). This led to the enactment of legislation which mandates that $50 \%$ of consignments of egusi and their derived products from Nigeria be checked before being allowed entry into the EU $(202,203)$.

Pivoting on what has already started in Africa, mentioned "building blocks" deserve strengthening and improvement. Based on the $\mathrm{OH}$ approach, mycotoxin reduction and control are dependent on the concerted efforts of all actors and stakeholders along the food production chain. We highlight here:

- Political will to address mycotoxins exposure and support capacity for testing commodities, which determines whether requirements can be enforced (162). As in the General Food Law issued by the EC, that clearly describes the food safety framework in the EU, including the role and responsibilities of the different parties involved from farm to fork, a envisaged African general food law could have a hierarchic and network character (21).

- Strengthened laboratory capacities, including efficient, cost-effective sampling, and analytical methods. Indeed, scientific research is moving toward reliable but cost-effective and sustainable user-friendly techniques for the acquisition of analytical data under field conditions and environmental stress (204).

- Nationwide surveillance and regular monitoring capacities by increased food and feed inspections (200).

- Established early warning systems as well as risk management systems allowing timely corrective actions and avoiding both food losses and waste (205).

- Training and empowerment of farmers and food producers on the good agricultural and good management practices. Indeed, communities are the foundation of Public health (205).

- Improvement of facilities. Many African countries do not have the infrastructures to prevent and control food contamination (e.g., Figure 1): science could give low cost solution to long lasting problems of infrastructures.

- Consumer awareness and education. According to Ezekiel et al. (65), at least $85 \%$ of the consumers of kulikuli in Nigeria are not aware of the risk of AF contamination of vended peanut cake. Consumers should prefer food producers adopting good practices.

- Dissemination of information via national media (radios, television, newspapers and magazines, and town hall meetings) and the web (206).

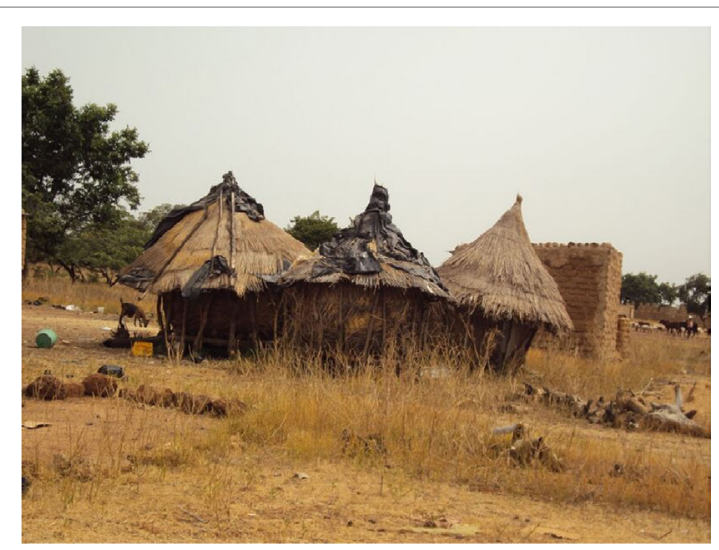

FIGURE 1 | Granaries in Burkina Faso, 2012 (courtesy of llaria Proietti, NOODLES Alliance)

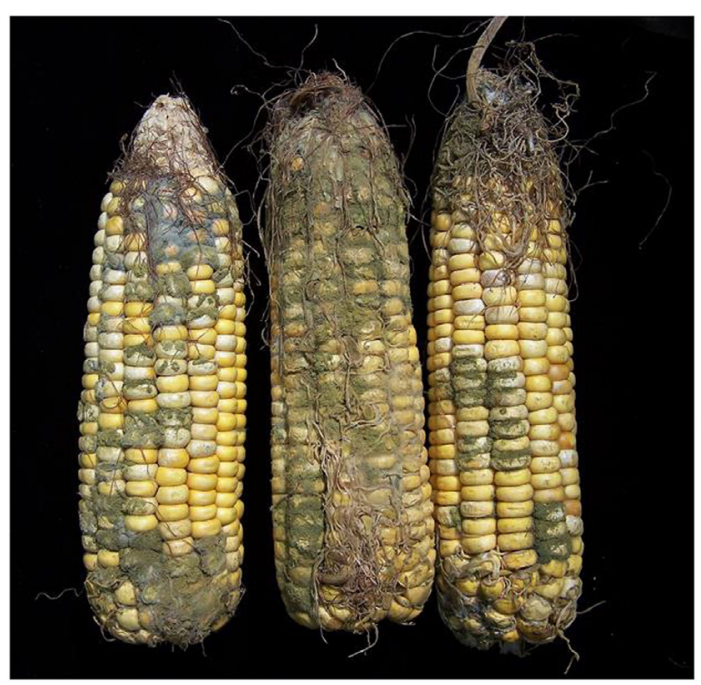

FIGURE 2 | Photograph of mycotoxin contaminated food: reproduced from Environmental Health Perspectives; September 2013, Volume 121, Issue 9, doi:10.1289/ehp.121-A270.

- Food processors or industry should contribute to an improved economic sustainability and enhanced international trade [see, e.g., reflections in Ref. (207)].

- The "luxury" of choice Figure 2. In countries where populations are facing starvation or where regulations are either not enforced or non-existent, chronic intake of AF may occur liver cancer incidence rates are 2-10 times higher in economically developing countries than in economically developed ones. Unfortunately, strict limitation of AF contaminated food is not always an option. A joint FAO/WHO/United Nations Environment Programme Conference report stated that in some economically developing countries, where food supplies are already limited, drastic legal measure may lead to food security problems, e.g., lack of food and excessive prices. It must be remembered that people living in these countries cannot exercise the option of starving to death today to live a better life tomorrow (150). 
The following are some more aspects that deserve deep attention:

- Risk analysis is increasingly recognized as an essential component in modern science-based food safety systems and plays a growing and important role in guiding food safety authorities. Informed by the risk assessment process, risk management in its broadest sense involves the consideration and implementation of food policy options, while taking due cognizance of tolerable levels of risk. Risk communication involves the interchange of information concerning risk and its perception among all stakeholders in food safety, including policy makers, industry, and consumers $(208,209)$.

- Risk to benefit assessment. Interestingly, some of the food items that are prone to mycotoxins contamination are component of healthy diet. Based on RASFF reports, the most predominant category of mycotoxins is $\mathrm{AF}$ in pistachios, peanuts, almonds, hazelnuts, and Brazil nuts. OTA occurs mainly in beverages (raw coffee and derivatives, cocoa powder), fruit and processed fruits (mainly raisins/sultanas and figs), spices and condiments (mainly pepper), vegetables, cereals, and other crops (202). Models for risk to benefit assessment are increasingly available (210).

\section{CONCLUSION}

Operationalization of $\mathrm{OH}$ for mycotoxins can shield population from direct (on health) and indirect (on trade, economies, and

\section{REFERENCES}

1. Frazzoli C, Mantovani A. Toxicants exposures as novel zoonoses, reflections on sustainable development, food safety and veterinary public health. Zoonoses Public Health (2010) 57:e136-42. doi:10.1111/j. 1863-2378.2009.01309.x

2. The American Veterinary Medical Association, One Health Initiative Task Force. Final Report, One Health: A New Professional Imperative. (2008). USA: American Veterinary Medical Association.

3. Okello AL, Bardosh K, Smith J, Welburn SC. One health, past successes and future challenges in three African contexts. PLoS Negl Trop Dis (2014) 8(5):e2884. doi:10.1371/journal.pntd.0002884

4. Frazzoli C, Mantovani A, Esposito R. Sustainable food safety and toxicant zoonoses, new prevention challenges in global health governance. Quaderni della Società Italiana di Medicina Tropicale e Salute Globale (2016) 1:117-27.

5. IFST. Mycotoxins. FSTS Magazine. (2009). Available from: https://www.ifst. org/knowledge-centre/information-statements/mycotoxins

6. Rocha ME, Freire F, Maia F, Guedes M, Rondina D. Mycotoxins and their effects on human and animal health. Food Control (2014) 36:159-65. doi:10.1016/j.foodcont.2013.08.021

7. Zaki MM, El-Midany SA, Shaheen HM, Rizzi L. Mycotoxins in animals, occurrence, effects, prevention and management. J Toxicol Environ Health Sci (2012) 4(1):13-28. doi:10.5897/JTEHS11.072

8. Tognarelli J, Ladep NG, Crossey MM, Okeke E, Duguru M, Banwat E, et al. Reasons why West Africa continues to be a hotbed for hepatocellular carcinoma. Niger Med J (2015) 56(4):231-5. doi:10.4103/0300-1652. 165032

9. Blandino M, Reyneri A, Colombari G, Pietri A. Comparison of integrated field programmes for the reduction of fumonisin contamination in maize kernels. Field Crops Res (2009) 111:284-9. doi:10.1016/ j.fcr.2009.01.004 livelihoods) effects of mycotoxins. Mycotoxins effects on public health and economy in Africa are not directly measurable, though its existence is indicated by environmental, toxicological, and clinical data. The contamination of food and feed by mycotoxins represents a serious health problem as well a considerable economic obstacle in African countries, where the trade balance is based on the exportation of commodities. Nowadays, the poorest regions of the world have neither the infrastructures to prevent and control food contamination, nor the luxury to allow the rejection of contaminated food. Operationalizing mycotoxins in the $\mathrm{OH}$ frame is useful to build a risk management frame that is sound and understandable in terms of empirical observations by local institutional stakeholders expected to issue risk management programs in Africa. Indeed, governance schemes for early prevention of toxic exposures deserve inclusion in development initiatives.

\section{AUTHOR CONTRIBUTIONS}

$\mathrm{CL}, \mathrm{CF}$, and $\mathrm{OO}$ contributed equally from the literature search, write-up, and revision of this article.

\section{FUNDING}

The work stems from activities of the network Noodles (www. noodlesonlus.org) within the project ALERT (www.alert2015.it) under the Call "Industry 2015."

10. Ezekiel CN, Warth B, Ogara IM, Abia WA, Ezekiel VC, Atehnkeng J, et al. Mycotoxin exposure in rural residents in northern Nigeria, a pilot study using multi-urinary biomarkers. Environ Int (2014) 66:138-45. doi:10.1016/ j.envint.2014.02.003

11. Bannink F, Larok R, Kirabira P, Bauwens L, van Hove G. Prevention of spina bifida, folic acid intake during pregnancy in Gulu district, northern Uganda Pan Afr Med J (2015) 20:90. doi:10.11604/pamj.2015.20.90.5338

12. Shirima CP, Kimanya ME, Routledge MN, Srey C, Kinabo JL, Humpf HU, et al. A prospective study of growth and biomarkers of exposure to aflatoxin and fumonisin during early childhood in Tanzania. Environ Health Perspect (2015) 123(2):173-8. doi:10.1289/ehp.1408097

13. Adekanmbi VT, Uthman OA, Mudasiru OM. Exploring variations in childhood stunting in Nigeria using league table, control chart and spatial analysis. BMC Public Health (2013) 18(13):361. doi:10.1186/ 1471-2458-13-361

14. Khlangwiset $P$, Shephard GS, Wu F. Aflatoxins and growth impairment, a review. Crit Rev Toxicol (2011) 41(9):740-55. doi:10.3109/10408444.2011. 575766

15. Turner PC, Flannery B, Isitt C, Ali M, Pestka J. The role of biomarkers in evaluating human health concerns from fungal contaminants in food. Nutr Res Rev (2012) 25:162-79. doi:10.1017/S095442241200008X

16. Lindahl J, Grace D, Harvey J, Kang'ethe E. Aflatoxins in East Africa, the importance of getting the full picture. Afr J Food Agric Nutr Dev (2016) 3(16):1-4.

17. Hussein HS, Brasel JM. Toxicity, metabolism, and impact of mycotoxins on humans and animals. Toxicology (2001) 167:101-34. doi:10.1016/ S0300-483X(01)00471-1

18. Wang JS, Groopman JD. DNA damage by mycotoxins. Mutat Res (1999) 424:167-81. doi:10.1016/S0027-5107(99)00017-2

19. Zain M. Impact of mycotoxins on humans and animals. J Saudi Chem Soc (2011) 15:129-44. doi:10.1016/j.jscs.2010.06.006 
20. Iqbal SZ, Asi MR, Selamat J. Aflatoxin M1 in milk from urban and rural farmhouses in Punjab, Pakistan. Food Addit Contam (2014) 7(1):17-20. doi:10.1080/19393210.2013.828322

21. Frazzoli C, Mazzanti F, Achu MB, Pouokam GB, Fokou E. Elements of kitchen toxicology to exploit the value of traditional (African) recipes: the case of Egusi Okra meal in the diet of HIV+/AIDS subjects. Toxicol Rep (2017) 4:474-83. doi:10.1016/j.toxrep.2017.06.008

22. Frazzoli C, Gherardi P, Saxena N, Belluzzi G, Mantovani A. The hotspot for (global) one health in primary food production: aflatoxin M1 in dairy products. Front Public Health (2017) 2(4):294. doi:10.3389/fpubh. 2016.00294

23. Monda E, Alakonya AE. A review of agricultural aflatoxin management strategies and emerging innovations in sub-Saharan Africa. Afr J Food Agric Nutr Dev (2016) 16(3):11126-38. doi:10.18697/ajfand.75.ILRI11

24. Cheng R, Mantovani A, Frazzoli C. Analysis of food safety and security challenges in emerging African food producing areas through a One Health lens, the dairy chains in Mali. J Food Prot (2016) 80(1):57-67. doi:10.4315/0362-028X.JFP-15-561

25. Darwish WS, Ikenaka Y, Nkayama SM, Ishizuka M. An overview of mycotoxin contamination of foods in Africa. J Vet Med Sci (2014) 76:789-97. doi:10.1292/jvms.13-0563

26. Wild CP, Hasegawa R, Barraud L, Chutimataewin S, Chapot B, Ito N, et al. Aflatoxin-albumin adducts, a basis for comparative carcinogenesis between animals and humans. Cancer Epidemiol Biomarkers Prev (1996) 5(3):179-89.

27. Brera C, Caputi R, Miraglia M, Iavicoli I, Salerno A, Carelli G. Exposure assessment to mycotoxins in workplaces, aflatoxins and ochratoxin A occurrence in airborne dusts and human sera. Microchem J (2002) 73:167-73. doi:10.1016/S0026-265X(02)00061-9

28. Marin S, Ramos AJ, Cano-Sancho G, Sanchis V. Mycotoxins, occurrence, toxicology, and exposure assessment. Food Chem Toxicol (2013) 60:218-37. doi:10.1016/j.fct.2013.07.047

29. Sirot V, Fremy J-M, Leblanc JC. Dietary exposure to mycotoxins and health risk assessment in the second French total diet study. Food Chem Toxicol (2013) 52:1-11. doi:10.1016/j.fct.2012.10.036

30. Abia WA, Warth B, Sulyok M, Krska R, Tchana A, Njobeh PB, et al. Biomonitoring of mycotoxin exposure in Cameroon using a urinary multibiomarker approach. Food Chem Toxicol (2013) 62:927-34. doi:10.1016/ j.fct.2013.10.003

31. Wu F, Munkvold G. Mycotoxins in ethanol co-products: modeling economic impacts on the livestock industry and management strategies. J Agric Food Chem (2008) 56(11):3900-11. doi:10.1021/jf072697e

32. Ogietor IS, Ikenebomeh MJ, Ekundayo AO. The bioload and aflatoxin content of market garri from some selected states in southern Nigeria, public health significance. Afr Health Sci (2007) 7(4):223-7.

33. Bankole SA, Adebanjo A. Mycotoxins in food in West Africa, current situation and possibilities of controlling it. Afr J Biotechnol (2003) 2:254-63. doi:10.5897/AJB2003.000-1053

34. Sibanda L, Marovatsanga LT, Pestka JJ. Review of mycotoxin work in subSaharan Africa. Food Control (1997) 8:21-9. doi:10.1016/S0956-7135(96) $00057-6$

35. Makun HA, Gbodi TA, Akanya HO, Sakalo AE, Ogbadu HG. Fungi and some mycotoxins contaminating rice (Oryza sativa) in Niger state, Nigeria. Afr J Biotechnol (2007) 6(2):99-108.

36. Ayejuyo OO, Williams AB, Imafidon TF. OTA burdens in rice from Lagos markets. Nigeria JEnviron Sci Technol (2008) 2(1):80-4. doi:10.3923/ jest.2008.80.84

37. Ikeorah J, Okoye ZS. Four Decades of Research on AFs in Nigeria, A Review of NSPRI Experience. Victoria Garden City, Lagos, Nigeria: Regional Workshop on Mycotoxins organized by National Agency for Food and Drug Administration and Control (NAFDAC) in collaboration with International Atomic Energy Agency (IAEA) (2005).

38. Makun HA, Kabiru AY, Dutton MF, Njobeh PB, Mwanza M. Natural multi-occurrence of mycotoxins in rice from Niger State, Nigeria. Mycotoxin Res (2011) 27:97-104. doi:10.1007/s12550-010-0080-5

39. CAST. Mycotoxins, risks in plant, animal, and human systems. Task Force Report No. 139. Ames: Council for Agricultural Science and Technology (2003).
40. European Union. Commission regulation (EC) $N^{\circ} 1881 / 2006$ of 19 December 2006. Setting maximum levels for certain contaminants in foodstuffs (text with EEA relevance). Off J Eur Union (2006) 364:5-24.

41. Warth B, Parich A, Atehnkeng J, Bandyopadhyay R, Schuhmacher R, Sulyok M, et al. Quantitation of mycotoxins in food and feed from Burkina Faso and Mozambique using a modern LC-MS/MS multitoxin method. JAgric Food Chem (2012) 60(36):9352-63. doi:10.1021/ jf302003n

42. Matumba L, Monjerezi M, Khonga EB, Lakudzala DD. Aflatoxins in sorghum, sorghum malt and traditional opaque beer in southern Malawi. Food Control (2011) 22(2):266-8. doi:10.1016/j.foodcont.2010.07.008

43. Mphande FA, Siame AB, Taylor JE. Fungi, aflatoxins and cyclopiazonic acid associated with peanut retailing in Botswana. J Food Prot (2004) 67:96-102. doi:10.4315/0362-028X-67.1.96

44. Idris YM, Mariod AA, Elnour IA, Mohamed AA. Determination of aflatoxin levels in Sudanese edible oils. Food Chem Toxicol (2010) 48:2539-41. doi:10.1016/j.fct.2010.05.021

45. Elshafie SZ, ElMubarak A, El-Nagerabi SA, Elshafie AE. Aflatoxin B1 contamination of traditionally processed peanuts butter for human consumption in Sudan. Mycopathologia (2011) 171:435-9. doi:10.1007/s11046010-9378-2

46. Kollia E, Tsourouflis K, Markaki P. Aflatoxin B1 in sesame seeds and sesame products from the Greek market. Food Addit Contam Part B Surveill (2016) 3(9):217-22. doi:10.1080/19393210.2016.1179349

47. Kimanya ME, De Meulenaer B, Tiisekwa B, Ndomondo-Sigonda M, Devlieghere F, Van Camp J, et al. Co-occurrence of fumonisins with aflatoxins in home-stored maize for human consumption in rural villages of Tanzania. Food Addit Contam Part A Chem Anal Control Expo Risk Assess (2008) 25:1353-64. doi:10.1080/02652030802112601

48. Manjula K, Hell K, Fandohan P, Abass A, Bandyopadhyay R. Aflatoxin and fumonisin contamination of cassava products and maize grain from markets in Tanzania and republic of the Congo. Toxin Rev (2009) 28:63-9. doi:10.1080/15569540802462214

49. Mukanga M, Derera J, Tongoona P, Laing MD. A survey of pre-harvest ear rot diseases of maize and associated mycotoxins in south and central Zambia. Int J Food Microbiol (2010) 141:213-21. doi:10.1016/j.ijfoodmicro. 2010.05.011

50. Kankolongo M, Hell K, Nawa IN. Assessment for fungal, mycotoxin and insects spoilage in maize stored for human consumption in Zambia. J Sci Food Agric (2009) 89:1366-75. doi:10.1002/jsfa.3596

51. Kitya D, Bbosa GS, Mulogo E. Aflatoxin levels in common foods of South Western Uganda: a risk factor to hepatocellular carcinoma. Eur J Cancer Care (Engl) (2010) 19:516-21. doi:10.1111/j.1365-2354.2009.01087.x

52. Kang'ethe EK, Lang'a KA. Aflatoxin B1 and M1 contamination of animal feeds and milk from urban centers in Kenya. Afr Health Sci (2009) 9: 218-26.

53. Daniel JH, Lewis LW, Redwood YA, Kieszak S, Breiman RF, Flanders WD, et al. ComprehensiveassessmentofmaizeaflatoxinlevelsinEasternKenya,2005-2007. Environ Health Perspect (2011) 119:1794-9. doi:10.1289/ehp.1003044

54. Lewis L, Onsongo M, Njapau H, Schurz-Rogers H, Luber G, Kieszak S, et al. Aflatoxin contamination of commercial maize products during an outbreak of acute aflatoxicosis in Eastern and Central Kenya. Environ Health Perspect (2005) 113:1763-7. doi:10.1289/ehp.7998

55. Mwihia JT, Straetmans M, Ibrahim A, Njau J, Muhenje O, Guracha A, et al. Aflatoxin levels in locally grown maize from Makueni district, Kenya. East Afr Med J (2008) 85(7):311-7. doi:10.4314/eamj.v85i7.9648

56. Mutegi CK, Ngugi HK, Hendriks SL, Jones RB. Prevalence and factors associated with aflatoxin contamination of peanuts from Western Kenya. Int $J$ Food Microbiol (2009) 13:27-34. doi:10.1016/j.ijfoodmicro.2008.12.030

57. Fufa H, Urga K. Screening of aflatoxins in Shiro and ground red pepper in Addis Ababa. Ethiop Med J (1996) 34:243-9.

58. Ayalew A, Fehrmann H, Lepschy J, Beck R, Abate D. Natural occurrence of mycotoxins in staple cereals from Ethiopia. Mycopathologia (2006) 162:57-63. doi:10.1007/s11046-006-0027-8

59. Adebajo LO. Survey of aflatoxins and ochratoxin A in stored tubers of Cyperus esculentus L. Mycopathologia (1993) 124:41-6. doi:10.1007/ BF01103055 
60. Bankole SA, Eseigbe DA. Occurrence of mycoflora and aflatoxins in marketed tiger nut. Crop Res (1996) 11:219-23.

61. Salifu A. Mycotoxins in short season sorghum in northern Nigeria. Samaru J Agric Res (1981) 1:83-8.

62. Bankole SA, Mabekoje OO. Mycoflora and occurrence of aflatoxin B1 in dried yam chips from markets in Ogun and Oyo States. Nigeria Mycopathol (2004) 157:111-5. doi:10.1023/B:MYCO.0000012211.31618.18

63. Bankole SA, Ogunsanwo BM, Eseigbe DA. Aflatoxins in Nigerian dry roasted groundnuts. Food Chem (2005) 89:503-6. doi:10.1016/j. foodchem.2004.03.004

64. Akano DA, Atanda O. The present level of aflatoxin in Nigerian groundnut cake ('kulikuli'). Lett Appl Microbiol (1990) 10(4):187-9. doi:10.1111/j.1472765X.1990.tb00111.x

65. Ezekiel CN, Sulyok M, Babalola DA, Warth B, Ezekiel VC, Krska R. Incidence and consumer awareness of toxigenic Aspergillus section Flavi and aflatoxin B 1 in peanut cake from Nigeria. Food Control (2013) 30(2):596-601. doi:10.1016/j.foodcont.2012.07.048

66. Ezekiel CN, Kayode FO, Fapohunda SO, Olorunfemi MF, Kponi BT. Aflatoxigenic moulds and aflatoxins in street-vended snacks in Lagos, Nigeria. Internet J Food Saf (2012) 14:83-8.

67. Ezekiel CN, Sulyok M, Warth B, Odebode AC, Krska R. Natural occurrence of mycotoxins in peanut cake from Nigeria. Food Control (2012) 27(2):338-42. doi:10.1016/j.foodcont.2012.04.010

68. Olajuyigbe OO, Akande GR, Ezekiel CN, Ezekiel MO. Aflatoxigenic moulds and aflatoxin contamination of retailed fishery products in Lagos markets. Mycotoxicology (2014) 1:57-63.

69. Oluwafemi F, Ibeh IN. Microbial contamination of seven major weaning foods in Nigeria. J Health Popul Nutr (2011) 29:415-9. doi:10.3329/jhpn. v29i4.8459

70. Makun HA, Adeniran AL, Mailafiya SC, Ayanda IS, Mudashiru AT, Ojukwu UJ, et al. Natural occurrence of ochratoxin A in some marketed Nigerian foods. Food Control (2013) 31(2):566-71. doi:10.1016/j. foodcont.2012.09.043

71. Kpodo KA. Mycotoxins in maize and fermented maize products in Southern Ghana. In: Cardwell KF, editor. Proceedings of the Workshop on Mycotoxins in Food in Africa. Cotonou, Benin: International Institute of Tropical Agriculture (1996). $33 \mathrm{p}$.

72. Kpodo K, Thrane U, Hald B. Fusaria and fumonisins in maize from Ghana and their co-occurrence with aflatoxins. Int J Food Microbiol (2000) 61:147-57. doi:10.1016/S0168-1605(00)00370-6

73. Hell K, Cardwell KF, Setamou M, Poehling HM. The influence of storage practices on aflatoxin contamination in maize in four agroecological zones of Benin, West Africa. JStored Prod Res (2000) 36:365-82. doi:10.1016/ S0022-474X(99)00056-9

74. Bassa S, Mestres C, Hell K, Vernia P, Cardwell K. First report of aflatoxin in dried yam chips in Benin. Plant Dis (2001) 85:1032. doi:10.1094/ PDIS.2001.85.9.1032A

75. Mestres C, Bassa S, Fagbohoun E, Nogo M, Hell K, Vernier P, et al. Yam chip food sub-sector: hazardous practices and presence of aflatoxins in Benin. J Stored Prod Res (2004) 40:575-85. doi:10.1016/j.jspr.2003.11.003

76. Houssou P, Ahohuendo BC, Fandohan P, Kpodo K, Hounhouigan DJ, Jakobsen M. Natural infection of cowpea (Vigna unguiculata (L.) Walp.) by toxigenic fungi and mycotoxin contamination in Benin, West Africa. J Stored Prod Res (2009) 45:40-5. doi:10.1016/j.jspr.2008.07.002

77. Hell K, Gnonlonfin BG, Kodjogbe G, Lamboni Y, Abdourhamane IK. Mycoflora and occurrence of aflatoxin in dried vegetables in Benin, Mali and Togo, West Africa. Int J Food Microbiol (2009) 135:99-104. doi:10.1016/j. ijfoodmicro.2009.07.039

78. Yameogo RT, Kassamba B. Aspergillus flavus and aflatoxin on tropical seeds used for snacks Arachis hypogaea, Balanites aegyptiaca and Sclerocarya birrea. Trop Sci (1999) 39:46-9.

79. Burger HM, Lombard MJ, Shephard GS, Rheeder JR, van der Westhuizen L, Gelderblom WC. Dietary fumonisin exposure in a rural population of South Africa. Food Chem Toxicol (2010) 48:2103-8. doi:10.1016/j.fct.2010. 05.011

80. Njobeh PB, Dutton M, Åberg A, Haggblom P. Estimation of multi-mycotoxin contamination in South African compound feeds. Toxins (2012) 4:836-48. doi:10.3390/toxins 4100836
81. Gilbert J. Review of Mycotoxins. Ministry of Agriculture, Fisheries and Food. Colney Lane, Norwich: Food Science Laboratory (1989).

82. Jimoh KO, Kolapo AL. Mycoflora and aflatoxin production in market samples of some selected Nigerian foodstuffs. Res J Microbiol (2008) 33:169-74.

83. Odoemelam SA, Osu CI. Aflatoxin B1 contamination of some edible grains marketed in Nigeria. J Chem (2009) 6(2):308-14. doi:10.1155/2009/708160

84. Rubert J, Fapohunda SO, Soler C, Ezekiel CN, Mañes J, Kayode F. A survey of mycotoxins in random street-vended snacks from Lagos, Nigeria, using QuEChERS-HPLC-MS/MS. Food Control (2013) 32(2):673-7. doi:10.1016/j. foodcont.2013.01.017

85. Ediage EN, Di Mavungu JD, Monbaliu S, Peteghem CV, De Saeger S. A validated multi-analyte LC-MS/MS method for the quantification of 25 mycotoxins in cassava flour, peanut cake and maize samples. J Agric Food Chem (2011) 59:5173-80. doi:10.1021/jf2009364

86. Fapohunda SO, Ogundero VW. Physiology of fungi associated with fast foods in Nigeria. Int Biodeterior (1990) 26(1):23-32. doi:10.1016/ 0265-3036(90)90033-4

87. Fapohunda SO, Anjorin ST, Akueche E, Harcourt B. Multi-mycotoxin profile of gamma-radiated sesame seeds from Abuja markets, Nigeria using LC-MS/ MS. Nat Sci (2012) 10(10):127-34.

88. Gbodi TA, Nwude N, Aliu YO, Ikediobi CO. The mycoflora and some mycotoxins found in maize (Zea mays) in the Plateau State of Nigeria. Vet Hum Toxicol (1986) 28(1):1-5.

89. CEC. Commission Regulation (EC) no. 1881/2006 of 19 December 2006 setting maximum levels for certain contaminants in foodstuffs. Off J Eur Union (2006) L364:5-24.

90. Sultan Y, Magan N. Mycotoxigenic fungi in peanuts from different geographic regions of Egypt. Mycotoxin Res (2010) 26:133-40. doi:10.1007/ s12550-010-0048-5

91. Cardwell KF, Cotty PJ. Distribution of Aspergillus flavus section Flavi among soils from the four agroecological zones of the Republic of Benin, West Africa. Plant Dis J (2002) 86:434-9. doi:10.1094/PDIS.2002.86.4.434

92. Probst C, Njapau H, Cotty PJ. Outbreak of an acute aflatoxicosis in Kenya in 2004, identification of the causal agent. Appl Environ Microbiol (2007) 73:2762-4. doi:10.1128/AEM.02370-06

93. Perrone G, Haidukowski M, Stea G, Epifani F, Bandyopadhyay R, Leslie JF, et al. Population structure and aflatoxin production by Aspergillus Sect. Flavi from maize in Nigeria and Ghana. Food Microbiol (2014) 41:52-9. doi:10.1016/j.fm.2013.12.005

94. Solfrizzo M, Gambacorta L, Visconti A. Assessment of multi-mycotoxin exposure in Southern Italy by urinary multi-biomarker determination. Toxins (2014) 6:523-38. doi:10.3390/toxins6020523

95. Wu F, Groopman JD, Pestka JJ. Public health impacts of foodborne mycotoxins. Annu Rev Food Sci Technol (2014) 5:351-572. doi:10.1146/ annurev-food-030713-092431

96. Wan LY, Turner PC, El-Nezami H. Individual and combined cytotoxic effects of Fusarium toxins (deoxynivalenol, nivalenol, zearalenone and fumonisins B1) on swine jejunal epithelial cells. Food Chem Toxicol (2013) 57:276-83. doi:10.1016/j.fct.2013.03.034

97. Wan ML, Woo CS, Allen KJ, Turner PC, El-Nezami H. Modulation of porcine $\beta$-defensins 1 and 2 upon individual and combined Fusarium toxin exposure in a swine jejunal epithelial cell line. Appl Environ Microbiol (2013) 79:2225-32. doi:10.1128/AEM.03277-12

98. Wan LY, Woo CS, Turner PC, Wan JM, El-Nezami H. Individual and combined effects of Fusarium toxins on the mRNA expression of proinflammatory cytokines in swine jejunal epithelial cells. Toxicol Lett (2013) 220:238-46. doi:10.1016/j.toxlet.2013.05.003

99. Wan ML, Allen KJ, Turner PC, El-Nezami H. Modulation of mucin mRNA (MUC5AC and MUC5B) expression and protein production and secretion in Caco-2/HT29-MTX co-cultures following exposure to individual and combined Fusarium mycotoxins. Toxicol Sci (2014) 39(1):83-98. doi:10.1093/toxsci/kfu019

100. Serrano AB, Font G, Ruiz MJ, Ferrer E. Co-occurrence and risk assessment of mycotoxins in food and diet from Mediterranean area. Food Chem (2012) 135:423-9. doi:10.1016/j.foodchem.2012.03.064

101. Somorin Y, Akinyemi A, Bertuzzi T, Pietri A. Co-occurrence of aflatoxins, ochratoxin A and citrinin in "egusi" melon (Colocynthis citrullus L.) seeds consumed in Ireland and the United Kingdom. Food Addit Contam Part B (2016) 9(3):230-5. doi:10.1080/19393210.2016.1183051 
102. Kimanya ME, Shirima CP, Magoha H, Shewiyo DH, De Meulenaer B, Kolsteren $\mathrm{P}$, et al. Co-exposures of aflatoxins with deoxynivalenol and fumonisins from maize based complementary foods in Rombo, Northern Tanzania. Food Control (2014) 41:76-81. doi:10.1016/j.foodcont.2013.12.034

103. Matumba L, Van Poucke C, Biswick T, Monjerezi M, Mwatseteza J, De Saeger S. A limited survey of mycotoxins in traditional maize based opaque beers in Malawi. Food Control (2014) 36(1):253-6. doi:10.1016/j. foodcont.2013.08.032

104. Ngoko Z, Daoudou, Imele H, Kamga PT, Mendi S, Mwangi M, et al. Fungi and mycotoxins associated with food commodities in Cameroon. J Appl Biosci (2008) 6:164-8.

105. Essono G, Ayodlea M, Akoab A, Fokoc J, Filtenborgd O, Olemboe S. Aflatoxin-producing Aspergillus spp. and aflatoxin levels in stored cassava chips as affected by processing practices. Food Control (2009) 20(7):648-54. doi:10.1016/j.foodcont.2008.09.018

106. Lane KS. New Support for FDA Regulation of Tobacco. (2005). Available from: www.Tobacco.org

107. Christensen GG. An overview of the food safety situation for the human population in African developing countries, a veterinary public health approach. In: Lindberg R, editor. Veterinary Medicine, Impacts on Human Health and Nutrition in Africa. Proceedings of an International Conference Held at International Livestock Research Institute (ILRI); 1995 Aug 27-31; Addis Ababa, Ethiopia (1995).

108. Bretholtz-Emanuelsson A, Olsen M, Oskarsson A, Palminger I, Hult K. Ochratoxin A in cow's milk and human milk with corresponding human blood samples. J AOAC Int (1993) 76:842-6.

109. Frazzoli C, Petrini C, Mantovani A. Sustainable development and next generation's health, a long-term perspective about the consequences of today's activities for food safety. Ann Ist Super Sanita (2009) 45(1):65-75.

110. Abbott SP. Mycotoxins and indoor molds. Indoor Environ Connect (2002) $3(4): 14-24$.

111. Horner WE, Worthan AG, Morey PR. Air-and dustbornem mycoflora in houses free of water damage and fungal growth. Appl Environ Microbiol (2004) 70(11):6394-400. doi:10.1128/AEM.70.11.6394-6400.2004

112. Viegas S, Veiga L, Malta-Vacas J, Sabino R, Figueiredo P, Almeida A, et al. Occupational exposure to aflatoxin (AFB1) in poultry production. J Toxicol Environ Health Part A (2012) 75:1330-40. doi:10.1080/15287394. 2012.721164

113. Viegas S, Veiga L, Veríssimo C, Sabino R, Figueiredo P, Almeida A, et al. Occupational exposure to aflatoxin B1 in swine production and possible contamination sources. J Toxicol Environ Health A Curr Issues (2013) 76(15):944-51. doi:10.1080/15287394.2013.826569

114. Viegas S, Veiga L, Verissimo C, Sabino R, Figueiredo P, Almeida A, et al. Occupational exposure to aflatoxin B1, the case of poultry and swine production. World Mycotoxin J (2013) 6(3):309-15. doi:10.3920/ WMJ2012.1531

115. Viegas S, Veiga L, Figueiredo P, Almeida A, Carolino E, Viegas C. Assessment of workers' exposure to aflatoxin B1 in a Portuguese waste industry. Ann Occup Hyg (2015) 59(2):173-81. doi:10.1093/annhyg/meu082

116. Ekhaise FO, Isitor EE, Idehen O, Emogbene OA. Airborne microflora in the atmosphere of a hospital environment of University of Benin Teaching Hospital (UBTH), Benin City, Nigeria. World J Agric Sci (2010) 6(2):166-70.

117. Awosika SA, Olajubu FA, Amusa NA. Microbiological assessment of indoor air of a teaching hospital in Nigeria. Asian Pac J Trop Biomed (2012) 2(6):465-8. doi:10.1016/S2221-1691(12)60077-X

118. Andersen B, Nissen A. Evaluation of media for detection of Stachybotrys and Chaetomium species associated with water-damaged buildings. Int Biodeterior Biodegradation. (2000) 46:111-6.

119. King N, Pierre A. Indoor air quality, fungi, and health. How do we stand? Can Fam Physician (2002) 48:298-302.

120. WHO. Children's Health and the Environment WHO Training Package for the Health Sector. World Health Organization. (2015). Available from: www.who.int/ceh

121. Williams J, Phillips TD, Jolly PE, Stiles JK, Jolly CM, Aggarwal D. Human aflatoxicosis in developing countries, a review of toxicology, exposure, potential health consequences, and interventions. Am J Clin Nutr (2004) 80:1106-22.
122. Gong YY, Egal S, Hounsa S, Hall AJ, Cardwell KF, Wild CP. Determinants of aflatoxin exposure in young children from Benin and Togo, West Africa, the critical role of weaning. Int J Epidemiol (2003) 32:556-62. doi:10.1093/ ije/dyg 109

123. Gong Y, Hounsa A, Egal S, Turner PC, Sutcliffe AE. Postweaning exposure to aflatoxin results in impaired child growth, a longitudinal study in Benin, West Africa. Environ Health Perspect (2004) 112:1331-8. doi:10.1289/ ehp.6954

124. Kensler TW, Roebuck BD, Wogan GN, Groopman JD. Aflatoxin, a 50-year odyssey of mechanistic and translational toxicology. Toxicol Sci (2011) 120:S28-48. doi:10.1093/toxsci/kfq283

125. Chao TC, Maxwell SM, Wong SY. An outbreak of aflatoxicosis and boric acid poisoning in Malaysia, a clinicopathological study. J Pathol (1991) 164:225-333. doi:10.1002/path.1711640307

126. Rheeder JP, Marasas WFO, Thiel PG, Sydenham EW, Shephard GS, Van Schalkwyk DJ. Fusarium moniliforme and fumonisins in corn in relation to human esophageal cancer in Transkei. Phytopathology (1992) 82:353-7. doi:10.1094/Phyto-82-353

127. Hsu IC, Metcalf RA, Sun T, Welsh JA, Wang NJ. Mutational hotspot in the p53 gene in human hepatocellular carcinomas. Nature (1991) 350:427-8. doi:10.1038/350427a0

128. Kirk G, Camus-Random AM, Goedert J, Hainaut P, Montesano R. p53 mutation in sera of patients with hepatocellular carcinoma and cirrhosis in The Gambia (West Africa) [Abstract]. Philadelphia: AACR 90th Annual Meeting. (Vol. 40) (1999). $41 \mathrm{p}$.

129. Williams JH, Grubb JA, Davis JW, Wang JS, Jolly PE, Ankrah NA, et al. HIV and hepatocellular and esophageal carcinomas related to consumption of mycotoxin-prone foods in sub-Saharan Africa. Am J Clin Nutr (2010) 92(1):154-60. doi:10.3945/ajcn.2009.28761

130. Sprando R, Collins T, Black T, Olejnik N, Rorie J, Eppley R, et al. Characterization of the effect of deoxynivalenol on selected male reproductive endpoints. Food Chem Toxicol (2005) 43:623-35. doi:10.1016/j. fct.2004.12.017

131. Malekinejad H, Schoevers EJ, Daemen IJ, Zijstra C, Colenbrander BM, Fine-Gremmels J, et al. Exposure to Fusarium toxins zearalenone and deoxynivalenol causes aneuploidy and abnormal embryo development in pigs. Biol Reprod (2007) 77:840-7. doi:10.1095/biolreprod.107.062711

132. Schoevers EJ, Fink-Gremmels J, Colenbrandera B, Roelen BA. Porcine oocytes are most vulnerable to the mycotoxin deoxynivalenol during formation of the meiotic spindle. Theriogenology (2010) 74:968-78. doi:10.1016/j.theriogenology.2010.04.026

133. Hou Y-J, Xiong B, Zheng W-J, Duan X, Cui X-S, Kim N-H, et al. Oocyte quality in mice is affected by a mycotoxin-contaminated diet. Environ Mol Mutagen (2014) 55(4):354-62. doi:10.1002/em.21833

134. Supriya C, Girish BP, Reddy PS. Aflatoxin\# B1-induced reproductive toxicity in male rats, possible mechanism of action. Int J Toxicol (2014) 33(3):155-61. doi:10.1177/1091581814530764

135. Tsakmakidis IA, Lymberopoulos AG, Khalifa TA, Boscos CM, Saratsi A, Alexopoulos C. Evaluation of zearalenone and $\alpha$-zearalenol toxicity on boar sperm DNA integrity. J Appl Toxicol (2008) 28:681-8. doi:10.1002/jat.1322

136. Lewis SE, Aitken RJ. DNA damage to spermatozoa has impacts on fertilization and pregnancy. Cell Tissue Res (2005) 322:33-41. doi:10.1007/ s00441-005-1097-5

137. Frizzell C, Verhaegen S, Ropstad E, Elliott CT, Connolly L. Endocrine disrupting effects of ochratoxin A at the level of nuclear receptor binding and steroidogenesis. Toxicol Lett (2013) 217:243-50. doi:10.1016/j. toxlet.2012.12.018

138. Frizzell C, Ndossi D, Verhaegen S, Dahl E, Eriksen G, Sørlie M, et al. Endocrine disrupting effects of zearalenone, alpha- and beta-zearalenol at the level of nuclear receptor binding and steroidogenesis. Toxicol Lett (2011) 206:210-7. doi:10.1016/j.toxlet.2011.07.015

139. Huuskonen P, Myllynenm P, Storvik M, Pasanen M. The effects of aflatoxin B1 on transporters and steroid metabolizing enzymes in JEG-3 cells. Toxicol Lett (2013) 218:200-6. doi:10.1016/j.toxlet.2013.01.015

140. Ndossi DG, Frizzell C, Tremoena NH, Faested CK, Verhaegena S, Dahla E, et al. An in vitro investigation of endocrine disrupting effects of trichothecenes deoxynivalenol (DON), T-2 and HT-2 toxins. Toxicol Lett (2012) 214:268-78. doi:10.1016/j.toxlet.2012.09.005 
141. Ibeh IN, Uriah N, Ogonor JI. Dietary exposure to aflatoxin in human male fertility in Benin City, Nigeria. Int J Fertil (1994) 39(4):208-14.

142. Uriah N, Ibeh NI, Oluwafemi F. A study on the impact of aflatoxins on human reproduction. Afr J Reprod Health (2001) 5(1):106-10. doi:10.2307/ 3583204

143. Adetoro OO, Ebomoyi EW. The prevalence of infertility in a rural Nigerian community. Afr J Med Med Sci (1991) 20:23-7.

144. Okonofua FE, Harris D, Odebiyi A, Thomas K, Snow RC. The social meaning of infertility in Southwest Nigeria. Health Trans Rev (1997) 7:205-20.

145. Larsen U. Primary and secondary infertility in sub-Saharan Africa. Int J Epidemiol (2000) 29:285-91. doi:10.1093/ije/29.2.285

146. Etuk SJ. Reproductive health: global infertility trend. Nigerian J Physiol Sci (2009) 24(2):85-90.

147. Carlsen E, Giwercman A, Keiding N, Skakkebæk NE. Evidence for decreasing quality of semen during past 50 years. BMJ (1992) 305(6854):609-13.

148. Eze UA, Okonofua FE. High prevalence of male infertility in Africa: are mycotoxins to blame? Afr J Reprod Health (2015) 19(3):9-17.

149. Caserta D, Mantovani A, Marci R, Fazi A, Ciardo F, La Rocca C, et al. Environment and women's reproductive health. Hum Reprod Update (2011) 17:418-33. doi:10.1093/humupd/dmq061

150. Bennett JW, Klich M. Mycotoxins. Clin Microbiol Rev (2003) 3(16):497-516. doi:10.1128/CMR.16.3.497-516.2003

151. Obuseh FA, Jolly PE, Jiang Y, Shuaib FM, Waterbor J, Ellis WO, et al. Aflatoxin $\mathrm{B} 1$ albumin adducts in plasma and aflatoxin $\mathrm{M} 1$ in urine are associated with plasma concentrations of vitamins A and E. Int J Vitam Nutr Res (2010) 80:355-68. doi:10.1024/0300-9831/a000021

152. Polychronaki N, Wild CP, Mykkanen H, Amra H, Abdel-Wahhab M, Sylla A, et al. Urinary biomarkers of aflatoxin exposure in young children from Egypt and Guinea. Food Chem Toxicol (2008) 46:519-26. doi:10.1016/j. fct.2007.08.034

153. Piekkola S, Turner PC, Abdel-Hamid M, Ezzat S, El-Daly M, El-Kafrawy S, et al. Characterisation of aflatoxin and deoxynivalenol exposure among pregnant Egyptian women. Food Addit Contam Part A Chem Anal Control Expo Risk Assess (2012) 29(6):962-71. doi:10.1080/19440049.2012.658442

154. Polychronaki N, Turner PC, Mykkanen H, Gong Y, Amra H, AbdelWahhab M, et al. Determinants of aflatoxin M1 in breast milk in a selected group of Egyptian mothers. Food Addit Contam (2006) 23:700-8. doi:10.1080/02652030600627222

155. Polychronaki N, West RM, Turner PC, Amra H, Abdel-Wahhab M, Mykkanen H, et al. A longitudinal assessment of aflatoxin M1 excretion in breast milk of selected Egyptian mothers. Food Chem Toxicol (2007) 45:1210-5. doi:10.1016/j.fct.2007.01.001

156. Turner PC, Burley VJ, Rothwell JA, White KL, Cade JE, Wild CP. Dietary wheat reduction decreases the level of urinary deoxynivalenol in UK adults. J Expo Sci Environ Epidemiol (2008) 18:392-9. doi:10.1038/s.jes.7500611

157. Jonsyn-Ellis FE. Seasonal variation in exposure frequency and concentration levels of aflatoxins and ochratoxins in urine samples of boys and girls. Mycopathologia (2001) 152(1):35-40. doi:10.1023/A:1011950512675

158. Nayak S, Sashidhar RB, Bhat RV. Quantification and validation of enzyme immunoassay for urinary aflatoxin B1-N7-guanine adduct for biological monitoring of aflatoxins. Analyst (2001) 126(2):179-83. doi:10.1039/b005778i

159. Turner PC, Moore SE, Hall AJ, Prentice AM, Wild CP. Modification of immune function through exposure to dietary aflatoxin in Gambian children. Environ Health Perspect (2003) 111:217-20. doi:10.1289/ehp.5753

160. Turner PC, Collinson AC, Cheung YB, Gong Y, Hall AJ. Aflatoxin exposure in utero causes growth faltering in Gambian infants. Int J Epidemiol (2007) 36:1119-25. doi:10.1093/ije/dym122

161. Jiang Y, Jolly PE, Ellis WO, Wang JS, Phillips TD, Williams JH. Aflatoxin B1 albumin adduct levels and cellular immune status in Ghanaians. Int Immunol (2005) 17:807-14. doi:10.1093/intimm/dxh262

162. Gnonlonfin GJ, Hell K, Adjovi Y, Fandohan P, Koudande DO, Mensah GA, et al. A review on aflatoxin contamination and its implications in the developing world, a sub-Saharan African perspective. Crit Rev Food Sci Nutr (2013) 53:349-65. doi:10.1080/10408398.2010.535718

163. Bhat RV, Vasanthi S. Mycotoxin food safety risks in developing countries. Food Safety in Food Security and Food Trade. Vision 2020 for Food, Agriculture and Environment, Focus 10, Brief 3 of 17. (2003). p. 1-2.

164. CDC. Outbreak of aflatoxin poisoning-eastern and central provinces, Kenya, January-July 2004. Morb Mortal Wkly Rep (2004) 53:790-3.
165. Okoth SA, Ohingo M. Dietary aflatoxin exposure and impaired growth in young children from Kisumu District, Kenya, cross sectional study. Afr $J$ Health Sci (2004) 11:43-54.

166. Shuaib FM, Jolly PE, Ehiri JE, Yatich N, Jian Y, Funkhouser E, et al. Association between birth outcomes and aflatoxin B1 biomarker blood levels in pregnant women in Kumasi, Ghana. Trop Med Int Health (2010) 15(2):160-7. doi:10.1111/j.1365-3156.2009.02435.x

167. Gong YY, Cardwell K, Hounsa A, Egal S, Turner PC. Dietary aflatoxin exposure and impaired growth in young children from Benin and Togo: cross sectional study. BMJ (2002) 325:20-1. doi:10.1136/bmj.325.7354.20

168. Proietti M, Del Buono A, Pagliaro G, Del Buono R, Di Rienzo C. The intestinal permeability syndrome, celiac disease, gluten sensitivity, autistic spectrum, mycotoxins and immunological tolerance. Med J Nutrition Metab (2013) 6(2):99-104. doi:10.1007/s12349-013-0125-3

169. Ueta E, Kodama M, Sumino Y, Kurome M, Ohta KI, Katagiri RI, et al. Genderdependent differences in the incidence of ochratoxin A-induced neural tube defects in the Pdn/Pdn mouse. Congenit Anom (2010) 50(1):29-39. doi:10.1111/j.1741-4520.2009.00255.x

170. Seno MM, Hu P, Gwadry FG, Pinto D, Marshall CR, Casallo G, et al. Gene and miRNA expression profiles in autism spectrum disorders. Brain Res (2011) 1380:85-97. doi:10.1016/j.brainres.2010.09.046

171. Tordjman S, Somogyi E, Coulon N, Kermarrec S, Cohen D, Bronsard G, et al. Gene $\times$ environment interactions in autism spectrum disorders, role of epigenetic mechanisms. Front Psychiatry (2014) 5:53. doi:10.3389/ fpsyt.2014.00053

172. Mezzelani A, Raggi ME, Marabotti A, Milanesi L. Ochratoxin A as possible factor trigging autism and its male prevalence via epigenetic mechanism. Nutr Neurosci (2016) 19(1):43-6. doi:10.1179/14768305 15Z.000000000186

173. Vasu MM, Anitha A, Thanseem I, Suzuki K, Yamada K, Takahashi T, et al. Serum microRNA profiles in children with autism. Mol Autism (2014) 5(1):1. doi:10.1186/2040-2392-5-40

174. Bakare MO, Munir KM. Autism spectrum disorders (ASD) in Africa, a perspective. Afr J Psychiatry (2011) 14(3):208-10. doi:10.4314/ajpsy. v14i3.3

175. Seif Eldin A, Habib D, Noufal A, Farrag S, Bazaid K, Al-Sharbati M. Use of M-CHAT for a multinational screening of young children with autism in the Arab countries. Int Rev Psychiatry (2008) 20(3):281-9. doi:10.1080/ 09540260801990324

176. Bakare MO, Bello-Mojeed MA, Munir KM, Ogun OC, Eaton J. Neurodevelopmental delay among children under the age of three years at immunization clinics in Lagos State, Nigeria-preliminary report. Sci Rep (2016) 6:25175. doi:10.1038/srep25175

177. Shephard GS, Leggott NL, Stockenström S, Somdyala NI, Marasas WF. Preparation of South African maize porridge, effect on fumonisin mycotoxin levels. S Afr J Sci (2002) 98:393-6.

178. Shephard GS, Marasas WF, Burger H-M, Somdyala NI, Rheeder JP, Van der Westhuizen L. Exposure assessment for fumonisins in the former Transkei region of South Africa. Food Addit Contam (2007) 24:621-9. doi:10.1080/02652030601101136

179. Shephard GS, Kimanya ME, Kpodo KA, Gnonlonfin GB, Gelderblom WC. The risk management dilemma for fumonisin mycotoxins. Food Control (2013) 34(2):596-600. doi:10.1016/j.foodcont.2013.05.019

180. Marasas WFO, Riley RT, Hendricks KA, Stevens VL, Sadler TW, Gelineauvan Waes J. Fumonisins disrupt sphingolipid metabolism, folate transport, and neural tube development in embryo culture and in vivo, a potential risk factor for human neural tube defects among populations consuming fumonisin-contaminated maize. J Nutr (2004) 134:711-6.

181. Kimanya ME, De Meulenaer B, Roberfroid D, Lachat C, Kolsteren P. Fumonisin exposure through maize in complementary foods is inversely associated with linear growth of infants in Tanzania. Mol Nutr Food Res (2010) 54:1659-67. doi:10.1002/mnfr.200900483

182. Stevens VL, Tang J. Fumonisin B1-induced sphingolipid depletion inhibits vitamin uptake via the glycosylphosphatidylinositol-anchored folate receptor. J Biol Chem (1997) 272:18020-5. doi:10.1074/jbc.272.29.18020

183. Gelineau-van Waes J, Starr L, Maddox J, Aleman F, Vos KA, Wilberding J. Maternal fumonisin exposure and risk for neural tube defects, mechanisms in an in vivo mouse model. Birth Defects Res A Clin Mol Teratol (2005) 73:487-97. doi:10.1002/bdra.20148 
184. Wild CP, Miller JD, Groopman JD. Mycotoxin control in low- and middleincome countries. IARC Working Group Reports No. 9. Lyon: International Agency for Research on Cancer (2015).

185. Kleter GA, Marvin HJ. Indicators of emerging hazards and risks to food safety. Food Chem Toxicol (2009) 47:1022-39. doi:10.1016/j.fct.2008.07.028

186. Cotty PJ, Jaime-Garcia R. Influences of climate on aflatoxin producing fungi and aflatoxin contamination. Int J Food Microbiol (2007) 119:109-15. doi:10.1016/j.ijfoodmicro.2007.07.060

187. Miraglia M, Marvin HJ, Kleter GA, Battilani P, Brera C, Coni E, et al. Toxicovigilance systems and practices in Africa. Toxics (2016) 4(13):1-16.

188. Streit E, Schatzmayr G, Tassis P, Tzika E, Marin D, Taranu I, et al. Current situation of mycotoxin contamination and co-occurrence in animal feed focus on Europe. Toxins (2012) 4:788-809. doi:10.3390/toxins4100788

189. Castelino JM, Dominguez-Salas P, Routledge MN, Prentice AM, Moore SE, Hennig BJ, et al. Seasonal and gestation stage associated differences in aflatoxin exposure in pregnant Gambian women. Trop Med Int Health (2014) 19(3):348-54. doi:10.1111/tmi.12250

190. Boudergue C, Burel C, Dragacci S, Favrot M-C, Fremy J-M, Massimi C, et al. Review of mycotoxin-detoxifying agents used as feed additives: mode of action, efficacy and feed/food safety. Scientific Report Submitted to the EFSA. EFSA-Q-2009-00839. Parma, Italy: European Food Safety Authority (2009).

191. Wagacha JM, Muthomi JW. Mycotoxin problem in Africa: current status, implications to food safety and health and possible management strategies. Int J Food Microbiol (2008) 124(1):1-12. doi:10.1016/j.ijfoodmicro.2008.01.008

192. Wild CP, Turner PC. The toxicology of aflatoxins as a basis for public health decisions. Mutagenesis (2002) 17(6):471-81. doi:10.1093/mutage/17.6.471

193. Prandini A, Tansini G, Sigolo S, Filippi L, Laporta M, Piva G. On the occurrence of aflatoxin M1 in milk and dairy products. Food Chem Toxicol (2009) 47:984-91. doi:10.1016/j.fct.2007.10.005

194. Prandini A, Toti L, van den Born GJ, Vespermann A. Climate change and food safety, an emerging issue with special focus on Europe. Food Chem Toxicol (2009) 47(5):1009-21. doi:10.1016/j.fct.2009.02.005

195. Stoev SD, Paskalev M, MacDonald S, Mantle PG. Experimental one year OTA toxicosis in pigs. Exp Toxicol Pathol (2002) 53:481-7. doi:10.1078/ 0940-2993-00213

196. NAN. News Agency of Nigeria. Abuja, Nigeria (2008).

197. Egmond HP, Schothorst RC, Jonker MA. Regulations relating to mycotoxins in food - perspectives in a global and European context. Anal Bioanal Chem (2007) 389:147-57. doi:10.1007/s00216-007-1317-9

198. Gimou MM, Pouillot R, Charrondière UR, Noel L, Guérin T, Leblanc J-C. Dietary exposure and health risk assessment for 14 toxics and essential trace elements in Yaounde: the Cameroonian Total Diet study. Food Addit Contam Part A (2014) 31(6):1064-80. doi:10.1080/19440049.2014.909953

199. Kamani TM, Kazwala R, Mfinanga S, Haydon D, Keyyu J, Lankester F, et al. One Health: a concept led by Africa, with global benefits. Vet Record (2015) 176:496-7. doi:10.1136/vr.h2461

200. Pouokam GB, Hamed H, Ngwafor R, Frazzoli C. Toxicovigilance systems and practices in Africa. Toxics (2016) 4:13. doi:10.3390/toxics4030013
201. Rapid Alert System for Food and Feed. Notification Details. Rapid Alert System for Food and Feed. European Commission, Health and Food Safety. (2012). Available from: https://ec.europe.eu/food/safety/rasff/index_en.htm

202. Kleter GA, Prandini A, Filippi L, Marvin HJ. Identification of potentially emerging food safety issues by analysis of reports published by the European Community's Rapid Alert System for Food and Feed (RASFF) during a four-year period. Food Chem Toxicol (2009) 47:932-50. doi:10.1016/j. fct.2007.12.022

203. Marvin HJP, Kleter GA, Prandini A, Dekkers S, Bolton DJ. Early identification systems for emerging foodborne hazards. Food Chem Toxicol (2009) 47:915-26. doi:10.1016/j.fct.2007.12.021

204. Dragone R, Grasso G, Muccini M, Toffanin S. Portable bio/chemosensoristic devices: innovative systems for environmental health and food safety diagnostics. Front Public Health (2017) 5:80. doi:10.3389/fpubh.2017.00080

205. Frazzoli C, Mantovani A, Dragone R. Local role of food producers' communities for a Global One-Health framework: the experience of translational research in an Italian dairy chain. J Agric Chem Environ (2014) 3(2B):14-9. doi:10.4236/jacen.2014.32B003

206. Frazzoli C, Asongalem EA, Orisakwe OE. Africa and scientific "prevention, education and research" networking: concluding remarks. In: Frazzoli C, Asongalem EA, Orisakwe OE, editors.Cooperazione Scientifica CamerunNigeria-Italia: la sanità pubblica veterinaria e la sicurezza alimentare sostenibile per la promozione della "one health/one prevention". Roma: Istituto Superiore di Sanità (2012). p. 197-8.

207. Boriani E, Esposito R, Frazzoli C, Fankte P, Hald T, Ruegg S. Framework to define structure and boundaries of complex health intervention systems: the ALERT project as example. Front Public Health (2017) 5:182. doi:10.3389/ fpubh.2017.00182

208. Shephard GG. Risk assessment of aflatoxins in food in Africa. Food Addit Contam (2008) 10(25):1246-56. doi:10.1080/02652030802036222

209. Shephard GS. Impact of mycotoxins on human health in developing countries. Food Addit Contam Part A Chem Anal Control Expo Risk Assess (2008) 25(2):146-51. doi:10.1080/02652030701567442

210. Mantovani A, Baldi F, Frazzoli C, Lorenzetti F, Maranghi F, editors. Modelli per la valutazione rischio-beneficio in sicurezza alimentare. Roma: Instituto Superiore di Sanità; Rapporti (ISTISAN 12/50) (2012).

Conflict of Interest Statement: The authors declare that the research was conducted in the absence of any commercial or financial relationships that could be construed as a potential conflict of interest.

Copyright (C) 2017 Ladeira, Frazzoli and Orisakwe. This is an open-access article distributed under the terms of the Creative Commons Attribution License (CC BY). The use, distribution or reproduction in other forums is permitted, provided the original author(s) or licensor are credited and that the original publication in this journal is cited, in accordance with accepted academic practice. No use, distribution or reproduction is permitted which does not comply with these terms. 